\title{
Size resolved characterization of the polysaccharidic and proteinaceous components of Sea Spray Aerosol
}

Josephine Y. Aller ${ }^{*}$, JoAnn C. Radway ${ }^{\mathrm{a}}$, Wendy P. Kilthau ${ }^{\mathrm{a}}$, Dylan W. Bothe ${ }^{\mathrm{a}}$, Theodore W. Wilson $^{\mathrm{b}}$, Robert D. Vaillancourt ${ }^{\mathrm{c}}$, Patricia K. Quinn ${ }^{\mathrm{d}}$, Derek J. Coffman ${ }^{\mathrm{d}}$, Benjamin J. Murray ${ }^{\mathrm{b}}$, and Daniel A. Knopf ${ }^{\text {a,e* }}$

${ }^{\text {a }}$ School of Marine and Atmospheric Sciences, Stony Brook University, Stony Brook, NY, USA

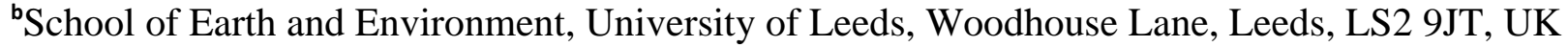

${ }^{\mathrm{c}}$ Department of Earth Sciences, Millersville University, Millersville, PA

${ }^{d}$ Pacific Marine Environmental Laboratory, National Oceanic and Atmospheric Administration, Seattle, Washington 98115, USA

${ }^{\mathrm{e}}$ Institute for Terrestrial and Planetary Atmospheres, Stony Brook University, Stony Brook, NY

*Corresponding authors. Tel. 1 631-632-8655. Fax. 1 631-632-8820; Tel. 2 631-632-3092. Fax. 2 631-632-6251

E-mail address. josephine.aller@ stonybrook.edu; daniel.knopf@ stonybrook.edu.

School of Marine and Atmospheric Sciences, Stony Brook University, Stony Brook, NY, 117945000 USA

Keywords.

Sea surface microlayer, transparent exopolymer material, protein-containing gel particles, sea spray aerosol, MOUDI 


\begin{abstract}
Dissolved organic polymers released by phytoplankton and bacteria abiologically self-assemble in surface ocean waters into nano- to micro-sized gels containing polysaccharides, proteins, lipids and other components. These gels concentrate in the sea surface microlayer (SML), where they can potentially contribute to sea spray aerosol (SSA). Sea spray is a major source of atmospheric aerosol mass over much of the earth's surface, and knowledge of its properties (including the amount and nature of the organic content), size distributions and fluxes are fundamental for determining its role in atmospheric chemistry and climate. Using a cascade impactor, we collected size-fractionated aerosol particles from ambient air and from freshly generated Sea Sweep SSA in the western North Atlantic Ocean together with biological and chemical characterization of subsurface and SML waters. Spectrophotometric methods were applied to quantify the polysaccharide-containing transparent exopolymer (TEP) and proteincontaining Coomassie stainable material (CSM) in these particles and waters. This study demonstrates that both TEP and CSM in surface ocean waters are aerosolized with sea spray with the greatest total TEP associated with particles $<180 \mathrm{~nm}$ in diameter and $>5000 \mathrm{~nm}$. The higher concentrations of TEP and CSM in particles > $5000 \mathrm{~nm}$ most likely reflects collection of microorganism cells and/or fragments. The greater concentration of CSM in larger size particles may also reflect greater stability of proteinaceous gels compared to polysaccharide-rich gels in surface waters and the SML. Both TEP and CSM were measured in the ambient marine air sample with concentrations of $2.1 \pm 0.16 \mu \mathrm{g}$ Xanthan Gum equivalents (XG eq.) $\mathrm{m}^{-3}$ and $14 \pm 1.0$ $\mu \mathrm{g}$ bovine serum albumin equivalents (BSA eq.) $\mathrm{m}^{-3}$. TEP in Sea Sweep SSA averaged $4.7 \pm 3.1$ $\mu \mathrm{g}$ XG eq. $\mathrm{m}^{-3}$ and CSM $8.6 \pm 7.3 \mu \mathrm{g}$ BSA eq. $\mathrm{m}^{-3}$. This work shows the transport of marine biogenic material across the air-sea interface through primary particle emission and the first demonstration of particle size discriminated TEP and CSM characterization of SSA and ambient aerosol under field conditions.
\end{abstract}




\section{Introduction}

A direct link between marine aerosol particles and surface water composition, which in turn is affected by the metabolic activities of planktonic microorganisms, has been postulated for over half a century (e.g. Zobell and Mathews, 1936; Stevenson and Collier, 1962; Blanchard, 1964; Wallace et al., 1972; Hoffman and Duce, 1974; Middlebrook et al., 1998; O'Dowd et al., 2004; Kuznetsova et al., 2005; Leck and Bigg, 2005a, b; Ceburnis et al., 2008; Facchini et al., 2008; Hawkins and Russell, 2010; Orellana et al., 2011; Ovadnevaite et al., 2011; Schmitt-Kopplin et al., 2012; Ovadnevaite et al., 2014). The sea-surface microlayer (SML), tens to hundreds of $\mu \mathrm{m}$ thick and comprising the ubiquitous uppermost layer, links the hydrosphere with the atmosphere, and is central to a range of global biogeochemical and climate-related processes (Lewis and Schwartz, 2004; Cincinelli et al., 2005; Cunliffe et al., 2012; de Leeuw et al., 2011; Gantt et al., 2011; Schill et al., 2015; Quinn et al., 2015; Burrows et al., 2016; Laskin et al., 2016). Like bulk seawater, the SML contains a complex mixture of inorganic particles, particulate organic matter in the form of microorganisms, debris (including bacterial cell walls and fragments of phytoplankton), as well as semitransparent organic particles and dissolved organic material (DOM) of phytoplankton and bacterial origin, some of which may adsorb onto inorganic particles. Recently, we have shown that phytoplankton cells and exudates can nucleate ice under tropospheric conditions with potential major implications for cloud formation, precipitation, the hydrological cycle, and climate (Alpert et al., 2011 a and b; Knopf et al., 2011, Wilson et al., 2015, Ladino et al., 2016).

Compared with bulk waters, the physical, chemical, and biological processes which lead to the spontaneous formation of suspended particles, "highly hydrated loose gels of tangled macromolecules and colloids" (Sieburth, 1983), are more intense in the SML because of its enrichment in surface-active polysaccharides (Wurl and Holmes, 2008). Polysaccharides are the dominant gel component, accounting for $\sim 30 \%$ of the DOM in the SML (Sieburth, 1983), and those $>0.4 \mu \mathrm{m}$ in radius are referred to as transparent exopolymer material (TEP) (e.g. Alldredge et al., 1993). Proteinaceous materials, which make up to $\sim 16 \%$ of the SML DOM (Sieburth, 1983), can also form gels or can be mixed with TEP and smaller polysaccharide-rich particles (Kuznetsova and Lee, 2001; Matrai et al., 2008; Cisternas-Novoa et al., 2015). Semi-quantitative methods of measuring the mass of particular gel types are available, but due to methodological limitations, gel size and state of mixing with other organic and inorganic materials in particles have not been well quantified, nor is gel formation well understood. This is partly because the most abundant gels are sub-micrometer in size (colloidal nanogels), although super-micrometer size gels (colloidal microgels) can also form (Passow, 2002; Verdugo et al., 2004; Verdugo et al., 2008; Verdugo and Sanchi, 2010; Verdugo, 2012). Current methods of measuring polysaccharide and proteinaceous materials in ocean waters involve staining with dyes that react with components of these materials, followed by 1) light microscopy or flow cytometry-based counting and measurement of stained particles, or 2) spectrophotometric determination of the total content of stainable material (TEP or Coomassie stainable material, for which we propose the term CSM to distinguish it from Coomassie stainable particles, which may or may not consist entirely of CSM) obtained by filtration of a known volume of liquid. Neither method, however, allows determination of the TEP or CSM content of individual particles in different size ranges. Nor can they tell anything about mixtures of polysaccharides with other macromolecules, including proteins and lipids, which may influence gel microstructure, formation, mixing, and 
size. Furthermore, field measurements often only calculate enrichment factors, thus avoiding the technical difficulties inherent to generating standard curves.

Overall productivity of surface waters, as well as the composition of the phytoplankton community, would be expected to influence abundances of polysaccharide-rich and protein-rich particles in the SML, with eutrophic waters differing from oligotrophic waters (e.g. Matrai et al., 2008; Gao et al., 2012). Productivity may also affect aerosol composition (O'Dowd et al., 2004). Although both types of particles form in ocean waters, they appear to have distinct characteristics and behaviors. Not only can the relative abundances vary with the dominant bloom species, but they can change during different phases of blooms and as the composition of the phytoplankton changes seasonally (e.g. Grossart et al., 1997, Berman and Viner-Mozzini, 2001; Cisternas-Novoa et al., 2015). These differences may translate into differences in the production flux of total SSA, the amount of organic material, and the chemical characteristics of the aerosolized organic component as shown by Alpert et al. (2015) and Cochran et al. (2016). We report on the links between exudate production in the SML, the size of SSA, and their polysaccharide and protein content which we are able to follow by modifying existing spectrophotometric methods for use with SSA which had been size fractionated by means of a 13 stage Multi Orifice Uniform Deposition Impactor (MOUDI Model 122R, MSP Corporation, Minneapolis, MN) Cascade impactor. Participation in the Western Atlantic Climate Study II (WACS II) provided the opportunity to test our approach, allowing us to collect SSA directly emitted from the ocean without interference of secondary processes such as the condensation of organic material from the gas phase. This was achieved by the use of an in situ particle generator, the Sea Sweep (Bates et al., 2012). In addition, we collected ambient particles in the same general ocean sampling area, but which briefly passed over Newfoundland and the biologically productive waters of Georges Banks and may have been affected by secondary processes during atmospheric transport.

The driving force behind this study was the need to better understand the chemical diversity of sea surface microlayers and associated SSA, which serve as the natural background marine source of atmospheric organic aerosols and are not well understood (e.g. Andreae, 2009; Ault et al., 2013, Frossard et al., 2014; Burrows et al., 2014). Specifically, size resolved characterization of aerosolized particles will allow us to better quantify the relative contribution of marine biologically derived organics to the total SSA mass. As far as we are aware, this is the first demonstration of aerosol particle size discriminated characterization of TEP and CSM for SSA and ambient aerosol under field conditions.

\section{Materials and methods}

\subsection{Sampling Stations}

Subsurface water, SML samples, freshly emitted SSA and ambient aerosol were collected off the R/V Knorr during the WACS II cruise in May 2014, which sampled both northern, colder, moderately productive waters of the western North Atlantic and the warmer waters of the Sargasso Sea, a region of typically low productivity (Table 1 and Fig. 1). Station numbers 1, 2, 3, 4 , and 5 were officially designated sampling locations. A location which we sampled on the day after the ship departed Station (Sta.) 1 was designated "1.1", and ambient air was sampled at " $2 / 3$ ", during transit between Stas. 2 and 3. Fluorometric measurements of maximum 
photosynthetic efficiency, a surrogate for potential primary productivity, were highest at northern stations (Stas. 1, 1.1, and 2) where the phytoplankton community was dominated by coccolithophores with dinoflagellates and green algae as lesser components. Of the stations we sampled, the lowest biological activity was found at Sta. 4, just west of Bermuda, where picocyanobacteria and small green algae predominated.

To assess the source of the ambient air sampled, 5 day back trajectories at 30, 50, and $100 \mathrm{~m}$ (approximate sampling height above sea level) were calculated from Sta. 2/3 using the Hybrid Single-Particle Lagrangian Integrated Trajectory (HYSPLIT) model (Draxler and Rolph, 2015; Rolph, 2015) (Fig.1). The 5 day back trajectories extend up to waters off southern Greenland at $\sim 63^{\circ} \mathrm{N}$ latitude, and indicate that the air mass ultimately sampled at Sta. 2/3 stayed in the marine boundary layer over open ocean western North Atlantic waters for several days, rapidly crossed over Newfoundland and had been over open ocean waters again for the 1.5 days before collecting the aerosol particles. Wide Field-of-view Sensor (SeaWIFS) (NASA; 25 May 2014) images covering the backward trajectories region during the same period show ocean water Chl $a$ concentrations in the moderate to productive range varying along the trajectory from at least 3 $\mu \mathrm{g} / \mathrm{L}$ off Greenland to $0.5 \mu \mathrm{g} / \mathrm{L}$ in waters off southwest of Newfoundland. Together these data suggest the potential for long distance transport of marine particles impacted by biological activity carried aloft by winds passing over ocean waters.

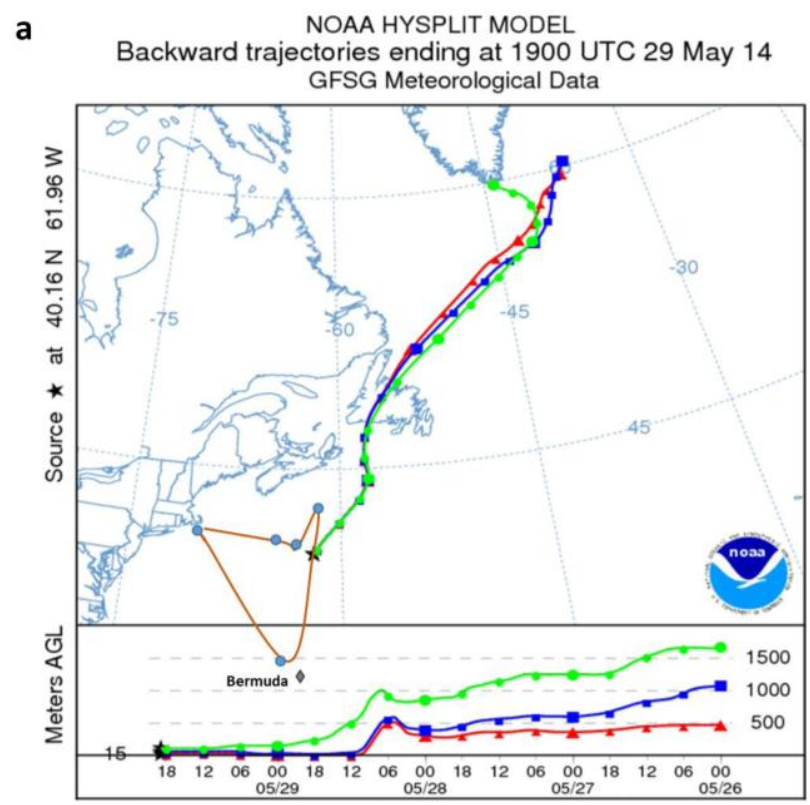

b

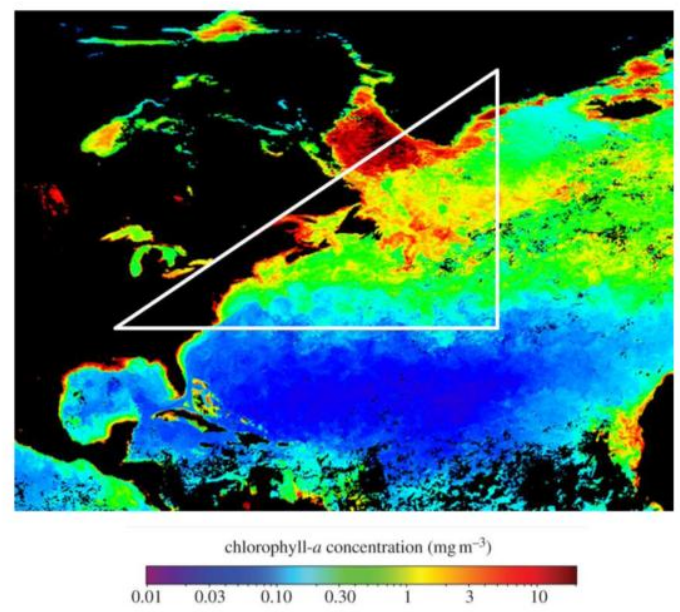

Fig. 1. Sampling locations during WACS II campaign, backward trajectories, and chlorophyll $a$ concentrations. (a) WACS II cruise track (brown line) with location of sampled stations. The HYSPLIT model air mass regime for the ambient air collection period is also shown, as calculated from 5-day back trajectories from Sta. 2/3 (indicated by the star at altitudes of 30, 50, and $100 \mathrm{~m}$ above sea level. (b) SeaWIFS (NASA; 25 May 2014) image at $9 \mathrm{~km}$ over the back trajectories region show ocean water $\mathrm{Chl} a$ concentrations in the moderate to productive range varying along the trajectory from 0.5 to at least $3 \mu \mathrm{g} / \mathrm{L}$ south off Greenland. 


\subsection{Collection and shipboard processing of water and SML samples}

Subsurface water, either from the ship's uncontaminated sampling intake at $5 \mathrm{~m}$ water depth or from a container lowered over the side of the ship to a depth of $0.5 \mathrm{~m}$, was collected into acid washed 250 and $500 \mathrm{ml}$ collapsible LDPE cubitainers (Thermo Fisher Scientific, Inc.). Aliquots for the various analyses were removed before the remaining water was preserved with $10 \mu l$ of $50 \% \mathrm{w} / \mathrm{v} \mathrm{ZnCl}_{2}$.

Sea state dictated the modes of sample collection and sometimes restricted the use of the rotating drum for SML sampling. Even direct contact with the ocean surface was limited at some stations, further complicating collection of the SML. Consequently, complete sample sets are not available for all stations.

Sea state permitting, SML samples were collected from the hydrophilic Teflon film coating of a rotating drum sampler mounted on the 'Interface II' battery operated remote-controlled catamaran (Wilson et al., 2015) modified from Harvey (1966) and Knulst et al. (2003). Due to the sea state during the WACS II campaign, the Interface II was tethered to the CTD arm of the $\mathrm{R} / \mathrm{V}$ Knorr on the starboard side of the ship during microlayer sampling. When the drum sampler was brought back onboard, accumulated microlayer water was transferred into $250 \mathrm{ml}$ cubitainers. Before and after sampling at each location, subsurface seawater from the ship's uncontaminated supply was flushed through the catamaran sampling system to clear any previously collected SML. Alternately, SML was collected on shipboard by the glass plate dipping method after Harvey and Burzell (1972), from a 250 gal tank filled with sea water from the ship's intake line, and then allowed to stand for an hour to establish a microlayer. It should be noted that the rotating drum sampler and the glass dipping method probe different thicknesses of the SML (e.g. Agogue et al., 2004; Cunliffe et al., 2011), thus making comparison difficult.

Table 1. Station locations, fluorometric Chl $a$ values from underway sampling of surface waters (generally 2-5 m below ocean surface), and relative non-chlorophyll $a$ light absorbing accessory pigment concentrations.Seawater samples for accessory pigments were collected within the upper mixed layer between 5 and 20 meters depth at the same locations as other data for stations $1,1.1,2$, and 3 , but were collected $71 \mathrm{~km}$ to the northwest of station 4 , and $43 \mathrm{~km}$ to the southeast of station 5 , both within a few hours. $\mathrm{n}=$ samples taken.

\begin{tabular}{|l|l|l|l|l|}
\hline Station & $\begin{array}{l}\text { Latitude } \\
(\mathbf{N})\end{array}$ & $\begin{array}{l}\text { Longitude } \\
(\mathbf{W})\end{array}$ & $\begin{array}{l}\text { Chl } \boldsymbol{a} \\
(\boldsymbol{\mu g} / \mathbf{L} \pm \mathbf{1} \mathbf{~ s d})\end{array}$ & $\begin{array}{l}\text { Accessory Pigments } \\
(\text { relative to Chl } \boldsymbol{a})\end{array}$ \\
\hline $\mathbf{1}$ & 40.38192 & 63.15497 & $0.331 \pm 0.084(\mathrm{n}=5)$ & Fuco $>$ Zea $>$ Hex-fuco \\
\hline $\mathbf{1 . 1}$ & 40.41558 & 62.33802 & $0.275 \pm 0.154(\mathrm{n}=8)$ & Zea $>$ Fuco $>$ Hex-fuco \\
\hline $\mathbf{2}$ & 42.48608 & 61.56345 & $2.219 \pm 0.226(\mathrm{n}=4)$ & Peri $>$ Hex-fuco $>$ Zea \\
\hline $\mathbf{3}$ & 40.16405 & 61.95833 & $0.429 \pm 0.207(\mathrm{n}=4-$ & Fuco $>$ Hex-fuco $>$ Zea \\
\hline $\mathbf{4}$ & 33.26817 & 62.90572 & $0.100 \pm 0.069(\mathrm{n}=4)$ & $\begin{array}{l}\text { Zea }>\text { Hex-fuco }>\text { But- } \\
\text { fuco }\end{array}$ \\
\hline $\mathbf{5}$ & 40.62100 & 70.40621 & $0.675(\mathrm{n}=1)$ & Hex-fuco $>$ Fuco = Zea \\
\hline
\end{tabular}

Abbreviations: Fuco = fucoxanthin; Zea = zeaxanthin; Hex-fuco = 19'-Hexanoyloxyfucoxanthin; But-fuco $=19$ '-Butanoyloxyfucoxanthin; Peri $=$ peridinin. 
Accessory pigment determinations and ratios to $\mathrm{Chl} a$ ratios allow for discrimination between phytoplankton classes (Mackey et al., 1996). Accessory pigment analyses were done on 0.75 to 2.2 L of seawater collected for high-performance liquid chromatography (HPLC) analyses from Niskin bottles or the ship's underway line and filtered through $25 \mathrm{~mm}$ Whatman® Glass microfiber filters, Grade GF/F filters at vacuum pressure of $150 \mathrm{~mm} \mathrm{Hg}$. Filters were subsequently folded in half, wrapped in aluminum foil, and stored in a liquid nitrogen dewar until shipped to the Goddard Space Flight Center HPLC laboratory (Greenbelt, MD) where the samples were extracted, separated, and quantified according to Van Heukelem and Thomas (2001), further described in Claustre et al. (2004).

\subsection{Analysis of seawater and SML samples}

Subsurface and microlayer water samples were sampled for quantification of TEP, CSM, dissolved organic carbon (DOC), particulate organic carbon (POC), particulate organic nitrogen (PON), and numbers of bacteria and algal cells. Duplicate $20 \mathrm{~mL}$ seawater samples were preserved either with Lugol's iodine (Throndsen, 1978) or neutralized sodium borate buffered formaldehyde solution (3\% final concentration) for enumeration of bacteria and phytoplankton. Bacterial and phytoplankton abundances were assessed using epifluorescence microscopy after staining with Acridine Orange (after Hobbie et al., 1977; Watson et al., 1977). Counting precision was better than 5\%. Phytoplankton were identified using light microscopy, enumerated and classified into broad taxonomic algal groups. Recorded volumes of seawater were passed through precombusted and preweighed GFF filters (nominal pore size $0.7 \mu \mathrm{m}$ ) for POC and PON analyses. Filters were kept frozen until analyzed. For DOC analyses, $40 \mathrm{~mL}$ samples of the filtered seawater were retained in precombusted glass vials and acidified to $\mathrm{pH} 1$ via dropwise addition of concentrated $\mathrm{HCl}$. Vials were then sealed with Teflon lined caps and stored at $4{ }^{\circ} \mathrm{C}$ until analysis. Acid cleaned glassware and filtration apparatus and precombusted $\left(550{ }^{\circ} \mathrm{C}\right)$ quartz fiber filters were used to collect and process all DOC and POC samples.

Dissolved organic carbon concentrations in water and SML samples were determined using a Shimadzu TOC-5000 DOC analyzer (1\% precision). Total $\mathrm{C}$ and $\mathrm{N}$ were measured using a Carlo-Erba 1102 CHNOS elemental analyzer (precision: C: 1-2\%; N: 2-3\%).

For measurements of TEP in SML and seawater, duplicate samples (50 to $250 \mathrm{ml}$ as needed) were filtered at low, constant vacuum $(<200 \mathrm{~mm} \mathrm{Hg})$ onto $25 \mathrm{~mm}$ diameter $0.4 \mu \mathrm{m}$ polycarbonate filters and stained with $500 \mu \mathrm{l}$ of $0.02 \%$ Alcian Blue in $0.06 \%$ acetic acid (pH 2.5) solution for 5 seconds, following the procedure of Passow and Alldredge (1995) as modified by Engel (2009) and Cisternas-Novoa et al. (2014). A Sartorius model 16315 filtration apparatus with a fluorocarbon-coated steel screen filter support was used. Stained filters were rinsed with 1 $\mathrm{ml}$ ultrapure water three times to remove excess dye and frozen until analysis in the laboratory. Samples for CSM quantification were similarly filtered, stained with $1 \mathrm{ml}$ of $0.04 \%$ Coomassie Brilliant Blue (CBB-G 250) dye at $\mathrm{pH} 7.4$ for 30-60 seconds, rinsed, stored frozen, and analyzed according to the procedure of Cisternas-Novoa et al. (2014).

Filters with stained TEP from water and the SML were extracted, a calibration curve constructed, and the results interpreted by the method described by Passow and Alldredge (1995) as modified by Engel (2009) and Cisternas-Novoa et al. (2014). The Alcian Blue solution used on shipboard was calibrated using a suspension of Xanthan Gum (XG). Filters with stained CSM from the SML or from seawater were analyzed and the results interpreted by the method of Cisternas-Novoa et al. (2014), using bovine serum albumin (BSA) as the standard for calibration 
of the Coomassie Blue solution used on shipboard. When making up new Alcian Blue or Coomassie Brilliant Blue dyes, new calibration curves have to be determined. Optical densities of samples, blanks (unexposed filter), and standards were measured at $787 \mathrm{~nm}$ using a Unico $2802 \mathrm{UV} /$ Vis spectrophotometer and a cell with a $1 \mathrm{~cm}$ path length. A Mettler XP6U ultra micro balance equipped with a U-Electrode Antistatic System was used for dry weight determinations on XG standards. TEP concentrations were reported in micrograms of XG equivalents per liter of air or nanograms per $\mathrm{ml}$ water. CSM concentrations were reported in micrograms of BSA equivalents per liter of air or nanograms BSA equivalents per mL water.

\subsection{Measurement of Aerosol Size Distributions}

Ambient aerosol particles were sampled from the inlet via a stainless steel tube on the mast extending $\sim 18 \mathrm{~m}$ above the sea surface. The mast was capped with a cone-shaped $5 \mathrm{~cm}$ diameter inlet nozzle that was rotated into the wind to maintain nominally isokinetic flow and minimize the loss of supermicron particles as described in Bates et al. (2012). Air was drawn through the inlet nozzle at $1 \mathrm{~m}^{3} \mathrm{~min}^{-1}$ to the lower $1.5 \mathrm{~m}$ of the tubing where it was heated for $\sim 2 \mathrm{sec}$ to $24 \pm$ $0.5^{\circ} \mathrm{C}$ to dry the aerosol to an $\mathrm{RH}$ of $\sim 60 \%$ (Bates et al., 2005).

SSA particles were generated by the in situ Sea Sweep nascent particle generator system designed by Bates and colleagues (Bates et al., 2012) which was deployed leeward of the R/V Knorr. This device's curtained frame protected a $\sim 0.5 \mathrm{~m}^{2}$ sea surface area from ambient air and aerosol particles. SSA particles were directly emitted from the ocean surface by bursting of bubbles generated $0.75 \mathrm{~m}$ below the water surface with particle-free air. A $5.1 \mathrm{~cm}$ ID NutriFLEX Pliovic $^{\text {TM }}$ hose attached to the top of the Sea Sweep brought SSA particles to the MOUDI and the scanning mobility particle sizer at a flow rate of $1 \mathrm{~m}^{3} \mathrm{~min}^{-1}$. Similar to sampling from the mast, in the lower $1.5 \mathrm{~m}$ of the tubing the aerosol was heated for $\sim 2 \mathrm{sec}$ to $24 \pm 0.5^{\circ} \mathrm{C}$ to dry the aerosol to a $\mathrm{RH}$ of $\sim 60 \%$ (Bates et al., 2005). Sampling times for particle collection by the MOUDI at each station are listed in Table 2. It should be noted that because bubble capture and flow rates can vary, absolute particle number concentrations from Sea Sweep generated SSA cannot be compared between stations.

The aerosol size distributions at $60 \%$ RH generated by the Sea Sweep and sampled from ambient air were determined using a Differential Mobility Particle Sizer (DMPS) equipped with a differential mobility particle sizer (Aitken-DMPS), a medium column differential mobility particle sizer (Accumulation-DMPS) and an aerodynamic particle sizer (APS model 3321, TSI, St. Paul, MN) in the aerodynamic particle diameter range from 0.02 to $11.38 \mu \mathrm{m}$ having an aerosol inlet with $10 \mu \mathrm{m} \mathrm{50 \%} \mathrm{cut-point.} \mathrm{Both} \mathrm{instruments} \mathrm{were} \mathrm{operated} \mathrm{at} 55 \pm 10 \% \mathrm{RH}$ and aerosol distributions were collected every 5 min and gridded in 96 size bins. The transmission efficiency for particles $<6.5 \mu \mathrm{m}$ (aerodynamic diameter) has been determined to be 95\% (Bates et al., 2002). Simultaneous measurements of the aerosol number size distribution made directly at the top of the Sea Sweep and at the base of the sampling mast showed no measurable loss of particles (Bates et al., 2012). The size distributions are a combination of DMPS and APS data where the APS aerodynamic diameters were converted to geometric diameters using densities calculated with the thermodynamic model, AeRho (Quinn and Coffman, 1998). The model uses inorganic ion and total organic carbon data from in-parallel running 7-stage impactors to estimate the density of the aerosol and the amount of water that is associated with the inorganic compounds at the measurement temperature and RH. The diameter channels in the overlap region of the DMPS and APS were chosen in the following manner: the last DMPS channel was 
discarded and the first APS diameter channel that was larger than the last valid DMPS channel was chosen as the first APS channel (Quinn et al.,, 1998; Quinn et al., 2002; Quinn et al., 2004). We report aerosol number and mass size distributions as a function of aerodynamic diameter for derivation of the total particulate mass sampled by the MOUDI as outlined below.

Table 2. MOUDI SSA sampling times at Sea Sweep stations during the 2014 WACS II cruise and of ambient air between Stations 2 and 3 which was sampled as the ship was underway (UTCCoordinated Universal Time).

\begin{tabular}{|c|c|c|}
\hline Station & $\begin{array}{c}\text { Sampling times } \\
\text { (UTC) }\end{array}$ & Sampling times (min) \\
\hline 1 & $142.6389-142.9063$ & 250 \\
\hline 1.1 & $143.5764-143.7813$ & 490 \\
\hline 2 & $146.5938-146.9514$ & 485 \\
\hline 4 & $152.7779-153.3757$ & 840 \\
\hline 5 & $155.8368-156.5521$ & 660 \\
\hline $2 / 3$ Ambient & $148.8646-148.9965$ & 405 \\
\hline
\end{tabular}

The aerosol number and mass size distributions in Figure 2 include the uncertainty due to the variation of the distribution during the sampling period (left panels) which represents $\pm 1 \sigma$ variation from the mean and the uncertainty due to the instrument counting statistics given by the counting statistics. Above $1 \mu \mathrm{m}$ the error is estimated to be 10\% (Bates et al., 2012, Pfeifer et al., 2016) while below $1 \mu \mathrm{m}$ counting statistics can yield an error which can be $>10 \%$. For the remainder of the document the combined uncertainties (sampling variability and counting are applied in the data analysis. This yields the most conservative error. As discussed below aerosol mass size distributions shown in Fig. 2 are used to derive the total particle mass (TPM) and its uncertainty for each stage sampled by MOUDI.

\subsection{Aerosol sampling with the cascade impactor MOUDI}

The MOUDI was kept in a humidity controlled instrumentation chamber at the base of the ship's mast. Inside the instrumentation chamber, a portion of the air was directed to the MOUDI at a flow rate of $30 \mathrm{~L} \mathrm{~min}^{-1}$. For analysis of particulate TEP and CSM concentrations as a function of aerosol particle size, replicate $13 \mathrm{~mm}$ diameter $0.2 \mu \mathrm{m}$ pore size polycarbonate filters were placed on each of the 9 uppermost stages of the MOUDI. Table 3 displays the corresponding cut-point diameters ranging from 100 to $10000 \mathrm{~nm}$ aerodynamic diameters.

As the $13 \mathrm{~mm}$ filters will only receive a fraction of the total number of deposited particles on a given stage and because the aerosol impaction area varies with the stage, the actual area of impaction for each stage was directly determined. Atomized sea salt particles were collected by the MOUDI onto foil liners covering each stage. The deposition area on each stage measured (Table 3) and confirmed by comparison with diameters given by Mason et al. (2015). The scaling factor, $S_{\text {corr }}$, given in Table 3 reflects the difference between the area of particles 


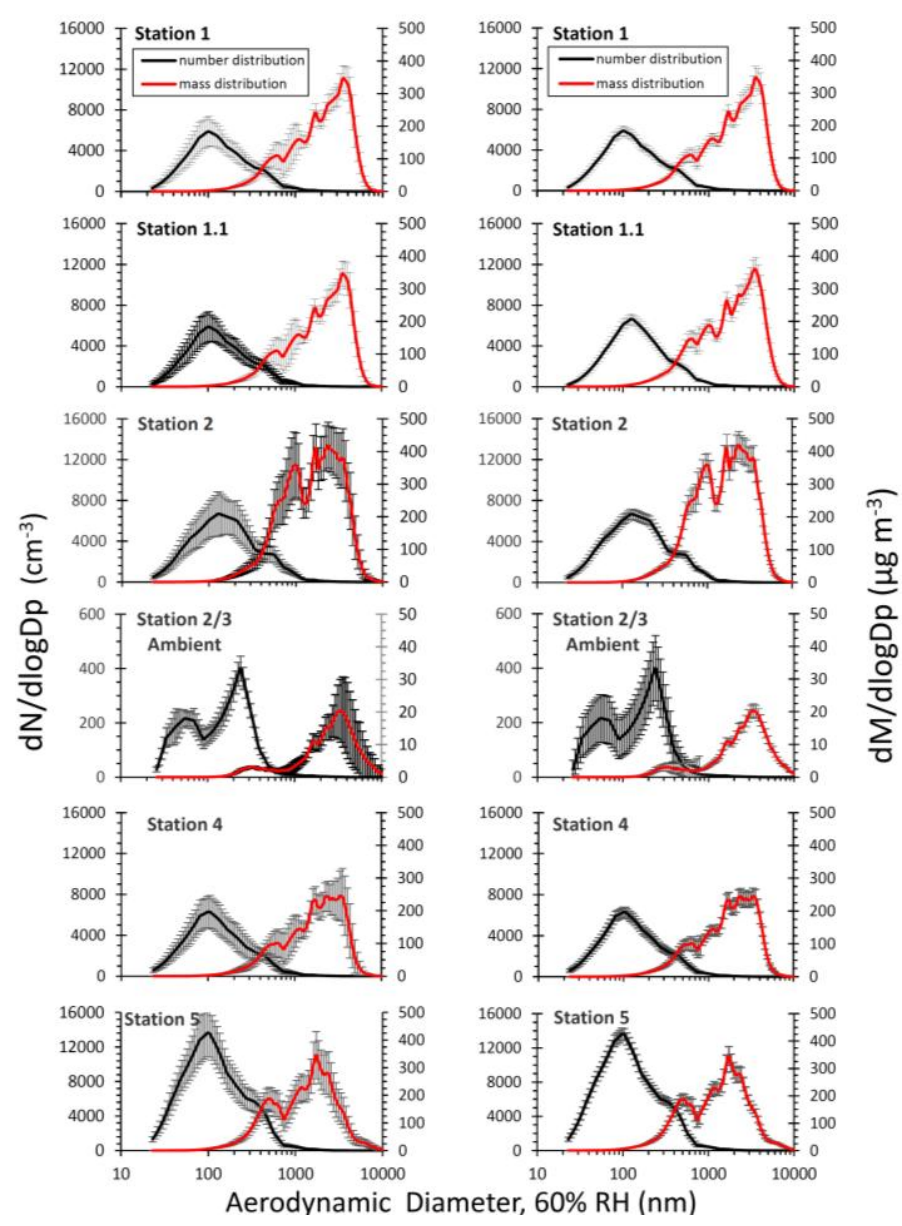

Fig. 2. Aerosol number (black line) and mass distribution (red line) as a function of aerodynamic diameter at $60 \% \mathrm{RH}$ derived from DMPS and APS measurements for Sea Sweep stations and ambient air collected at Sta. 2/3. Aerosol distributions are time-averaged at 5 min intervals, but only data acquired during MOUDI ${ }^{\mathrm{TM}}$ sample collection periods were considered (Table 2). Vertical error bars in the left column reflect sampling variability and represent 1 standard deviation. Error bars in distributions shown in the right column illustrate the uncertainty due to the DMPS/APS instrument counting.

was impacted onto filters which could be stained for TEP and CSM determination and the total impaction area of a given stage. This correction allowed for comparison of airborne TEP and CSM concentrations with TPM concentrations.

Table 3. MOUDI particle collection characteristics of each stage expressed as midpoint cut-point diameters given as equivalent aerodynamic diameters. The maximum uniformly impacted area per stage is given with corresponding scaling factor for the $9.5 \mathrm{~mm}$ diameter area of the $13 \mathrm{~mm}$ diameter filters where impacted particles were actually stained.

\begin{tabular}{|c|c|c|c|}
\hline Stage & $\begin{array}{c}50 \% \text { Cut-point } \\
(\mathrm{nm})\end{array}$ & $\begin{array}{c}\text { Deposit Area } \\
\left(\mathrm{nm}^{2}\right)\end{array}$ & $\begin{array}{l}\text { Scaling } \\
\text { Factor, } \mathrm{S}_{\text {corr }}\end{array}$ \\
\hline Inlet & & & \\
\hline 1 & 10000 & 424.6 & 5.99 \\
\hline 2 & 5600 & 424.6 & 5.99 \\
\hline 3 & 3200 & 541.2 & 7.63 \\
\hline 4 & 1800 & 541.2 & 7.63 \\
\hline 5 & 1000 & 541.2 & 7.63 \\
\hline 6 & 560 & 604.8 & 8.53 \\
\hline 7 & 320 & 583.2 & 8.23 \\
\hline 8 & 180 & 583.2 & 8.23 \\
\hline 9 & 100 & 583.2 & 8.23 \\
\hline
\end{tabular}


Sampling at $60 \%$ RH with the MOUDI was chosen to reduce particle losses due to bouncing, though we were not able to quantify this impact. MOUDI particle loss for liquid and solid particles is specified as follows (Marple, 1991). Between stages 3 and 8, particle loss is below $2 \%$. Particle loss increased towards $\sim 8 \%$ for stage 10 . The greatest particle losses are for the largest particle sizes, i.e. stages 1 and 2, reaching $20 \%$. The actual particle loss for the particles sampled in this study is not known. Therefore, the data analysis does not account for these losses. However, the data analysis presented below indicates similar or larger uncertainties in measured particle mass due to sampling of TPM and in TEP and CSM mass determination. Therefore, potential particle losses can be assumed to have a minor impact on presented data analysis.

No filters were placed on stages 10-13 (cut-point diameters 56, 32, $18,10 \mathrm{~nm}$ ) since TEP and CSM measurements on these small particles cannot yet be made as outlined below.

\subsection{Particulate TEP and CSM Measurements}

Polycarbonate filters were used to collect size fractionated SSA and ambient air samples for TEP and CSM analysis. These samples were stained on shipboard as described above for water samples. The $0.2 \mu \mathrm{m}$ pore size filters were removed from each stage of the MOUDI and immediately stained with $0.25-0.5 \mathrm{~mL}$ of $0.1 \mu \mathrm{m}$ filtered Alcian Blue or Coomassie Blue solutions for $5 \mathrm{sec}$ or $30 \mathrm{~s}$, respectively (the same time used for seawater samples), rinsed with 2 $\mathrm{mL}, 0.1 \mu \mathrm{m}$ filtered distilled water, and stored at $-20^{\circ} \mathrm{C}$. Particle-free filters were stained and rinsed along with each set of samples to serve as controls. For staining and rinsing of filters, a 13 mm glass filtration unit (Advantec KG13AA) was modified by replacement of the glass frit with a polypropylene filter support and the addition of an acrylic plate to restrict the staining/filtration area to $9.5 \mathrm{~mm}$. The current lower size limit of aerosol particles for TEP and CSM determination is about $100 \mathrm{~nm}$. Smaller particles, even if they swell during dying and rinsing, may not be sufficiently retained in the filter to assure accurate mass measurements.

Because of the small diameter of MOUDI stages and the need for simultaneous collection of other sample types, only three filters could be placed on any one stage, so two were used to collect particles for TEP analyses and one for CSM analysis. We therefore did not attempt multivariate statistical analyses of the data.

In order to determine the TEP portion of total aerosol mass we measured Alcian Blue-stained samples and reagent blanks on $13 \mathrm{~mm}$ filters, by modifying the colorimetric method of Passow and Alldredge (1995) as follows. Each aerosol sample on a $13 \mathrm{~mm}$ filter was extracted in a 10 $\mathrm{mL}$ borosilicate glass beaker for $2 \mathrm{~h}$ using $1.5 \mathrm{~mL}$ of $80 \%$ sulfuric acid, with swirling every 15 min. Optical densities were then measured at $787 \mathrm{~nm}$ against a distilled water instrument blank using a UV/Vis spectrophotometer and a semi micro cell with a $1 \mathrm{~cm}$ path length. To convert the measured absorbance into mass of TEP, the absorbance was calibrated using XG as a standard. Although the same Alcian Blue solution was used for all samples (seawater, SML, aerosol), the aerosol samples processed using our modified filtration apparatus required preparation of a separate calibration curve using $13 \mathrm{~mm}$ diameter, $0.2 \mu \mathrm{m}$ polycarbonate filters (Fig. 3). Our working solution was a tenfold dilution (in $0.1 \mu \mathrm{m}$ filtered distilled water) of XG standard which had been freshly prepared according to Cisternas-Novoa et al. (2014). Filters for dry weight measurements were prewashed, dried at $40{ }^{\circ} \mathrm{C}$, and cooled in a desiccator prior to weighing to a constant weight. The use of the ultra-micro balance and an antistatic system was critical to the 
successful generation of calibration curves due to the very low sample masses and substantial static charge issues.

A calibration curve for XG weights up to $0.12 \mu \mathrm{g}$ was constructed as follows. For calibration of each XG mass, three samples of a known volume of the XG working solution were divided into replicate aliquots. One aliquot for XG mass determination was collected on a preweighed filter, dried and weighed to a constant weight. The second aliquot was collected on a filter, dyed, extracted for $3 \mathrm{hr}$ in $80 \% \mathrm{H}_{2} \mathrm{SO}_{4}$ and the adsorption of the resulting solution measured at $787 \mathrm{~nm}$. In parallel to account for slight changes in dye retention from filter to filter, blank filters without $\mathrm{XG}$ were washed and dried, were dyed, extracted, and after 3 hours the adsorption of the resulting solution measured at $787 \mathrm{~nm}$. The mass of $\mathrm{XG}$ is then plotted against the difference in absorbance between the replicate filter containing XG and corresponding blank filter giving the net absorbance. From this procedure we were able to produce a calibration curve that is linear between 0 and $0.12 \mu \mathrm{g} \mathrm{XG} \mathrm{(Fig.} \mathrm{3).} \mathrm{For} \mathrm{the} \mathrm{lowest} \mathrm{or} \mathrm{zero} \mathrm{XG} \mathrm{masses,} \mathrm{slightly} \mathrm{negative} \mathrm{optical}$ density reading are possible due to slight retention of the dye within a filter even without the addition of $\mathrm{XG}$, resulting in some absorbance.

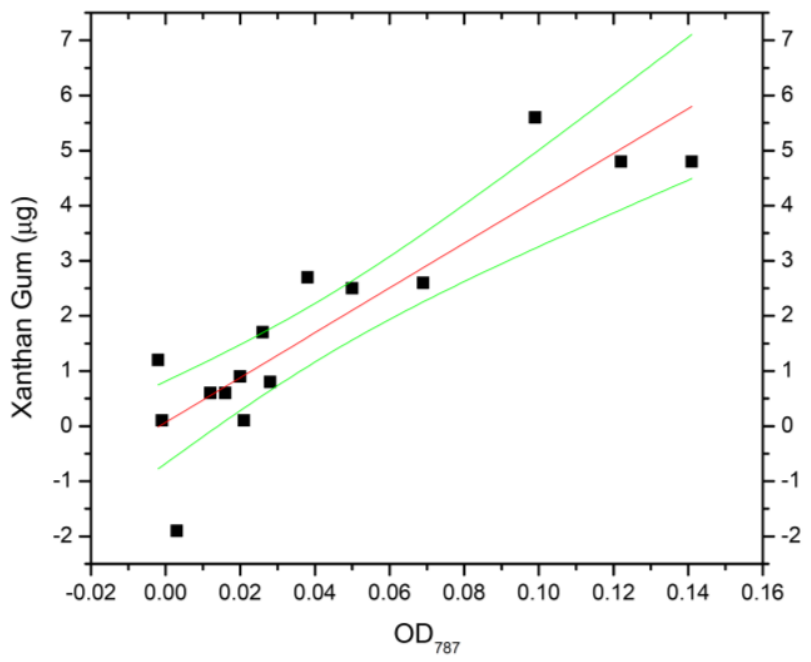

Fig. 3. An example of a TEP calibration curve (red) with $95 \%$ confidence bands $( \pm 1 \sigma$, green $)$ using xanthan gum as surrogate material and stained by Alcian Blue using a $13 \mathrm{~mm}$ diameter filter apparatus.

The calibration curve was not forced through the origin of the plot. The concentration of TEP determined in aerosol samples is then corrected for the fractional coverage of the MOUDI ${ }^{\mathrm{TM}}$ stage area (Table 2), normalized by the volume of air sampled, and expressed in micrograms of $\mathrm{XG}$ equivalents per liter of air $\left(\mu \mathrm{g} \mathrm{XG}\right.$ eq. $\left.\mathrm{L}^{-1}\right)$ as calculated by the equation:

$$
T E P\left(\mu g X G e q L^{-1}\right)=\left(T E P^{\text {sample }}-T E P^{\text {blank }}\right) / V^{\text {air }} \times S_{\text {corr }}
$$

where $T E P^{\text {sample }}$ is the TEP mass in $\mu \mathrm{g}$ of the aerosol, $T E P^{\text {blank }}$ is the TEP mass in $\mu \mathrm{g}$ of the blank filter (both derived from Fig. 3), and $V^{\text {air }}$ is the volume of air in liters which passed through the MOUDI. In cases where there were limited numbers of stainable particles in a given size bin, $T E P^{\text {sample }}-T E P^{\text {blank }} \approx 0$, representing our detection limit.

For CSM measurements from aerosol samples, $1 \mathrm{~mL}$ of $3 \%$ SDS in $50 \%$ isopropyl alcohol was added to the $5 \mathrm{~mL}$ cryo tubes used to store the stained filters. The samples were placed in a Fisher Scientific FS30H ultrasonic bath for $2 \mathrm{hr}$ at $37{ }^{\circ} \mathrm{C}$. Absorption of the eluted dye from 
samples and filtered seawater blanks was determined spectrophotometrically at $615 \mathrm{~nm}$ in a $1 \mathrm{~cm}$ path length semi micro cell against particle-free distilled water.

The Coomassie Brilliant Blue solution used on shipboard was calibrated for use with our method in the same manner employed for the Alcian Blue calibration for the TEP analysis described above. A BSA standard prepared according to Cisternas-Novoa et al. (2014) was diluted tenfold with $0.1 \mu \mathrm{m}$ filtered distilled water for generating a standard curve using $13 \mathrm{~mm}$ diameter, $0.2 \mu \mathrm{m}$ pore size filters. The calibration curve for CSM mass derivation is shown in Fig. 4. The calibration curve was not forced through the origin of the plot. As for the Alcian Blue standardization the dry weight (in $\mu \mathrm{g}$ ) of the BSA retained by filters was related to the Coomassie Brilliant Blue absorbance.

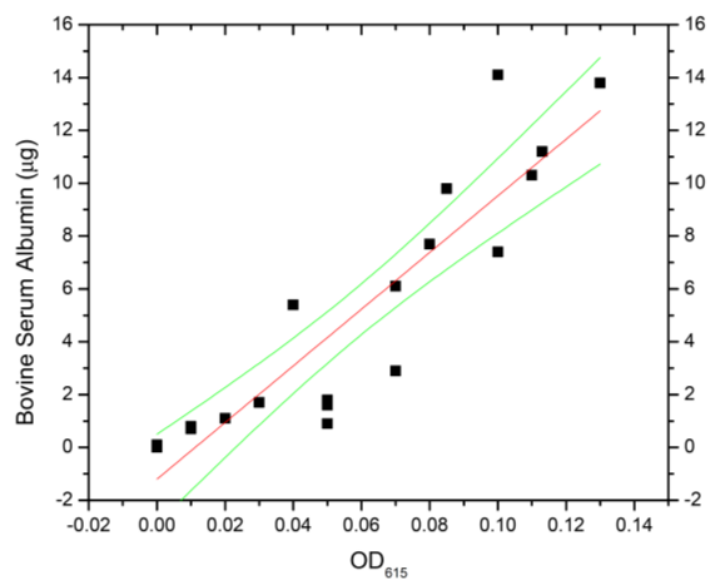

Fig. 4. An example of a CSM calibration curve (red) with $95 \%$ confidence bands $( \pm 1 \quad \sigma$, green) using bovine serum albumin as surrogate material and stained by Coomassie Brilliant Blue dye using a $13 \mathrm{~mm}$ filter apparatus.

Results are expressed in micrograms of BSA equivalents per liter air using the equation:

$$
\operatorname{CSM}\left(\mu g X G \text { eq } L^{-1}\right)=\left(C S M^{\text {sample }}-C S M^{\text {blank }}\right) / N^{\text {air }} \times S_{\text {corr }}
$$

where $C S M^{\text {sample }}$ is the CSM mass in $\mu \mathrm{g}$ of the aerosol, $C S M^{\text {blank }}$ is the CSM mass in $\mu \mathrm{g}$ of the blank filter (both derived from Fig. 4), and $V^{\text {air }}$ is the volume of air in liters which passed through the MOUDI. In cases where there were limited numbers of stainable particles in a given size bin, $C S M^{\text {sample }}-C S M^{\text {blank }} \approx 0$, representing our detection limit.

Application of Equations 1 and 2 yields the amount of TEP and CSM in collected aerosol particles, respectively, as a function of particle size given by respective MOUDI stage or when summed over all stages as total airborne TEP and CSM concentrations. Neglecting particle losses in MOUDI, the dominant uncertainty in derived TEP and CSM concentrations is due to calibration uncertainties as depicted in Figs. 3 and 4. In the typical TEP and CSM concentration range present on the MOUDI stages, the mass uncertainty is about 25 and $20 \%$, respectively.

\subsection{Estimation of TEP and CSM Concentrations in Collected Aerosol Particles.}

Assessment of the mass concentration of TEP and CSM in sampled aerosol particles as a function of size requires determination of TPM in each MOUDI stage. Since TPM for each MOUDI stage could not be determined independently, the continuously measured DMPS/APS aerosol mass size distributions are applied to give an estimate of TPM. To improve future analysis we recommend using two MOUDI setups in parallel, isokinetically sampling with same 
cut-point diameters, one collecting particles for determination of TEP and CSM and the other one to determine TPM per sampling stage.

To estimate the collected TPM, we first represent the MOUDI collection efficiency curves (Marple, 1991) by lognormal functions extending those beyond the given cut-point by $\pm 4 \sigma$ to assess the particle masses that are being collected per stage. As mentioned above, particle losses in MOUDI are not included in this analysis and will very likely have only a minor effect on the overall data uncertainty. The time averaged 96 binned DMPS/APS mass distribution data (Fig. 2) are sorted into the size range of individual MOUDI stages (Table 2) where overlaps in the collection efficiency curves have been accounted for. For example, a DMPS/APS size bin smaller than the cut-point diameter will result in 50\% and less of the particles being collected in that stage but more than $50 \%$ in the stage with smaller cut-point diameter. Subsequently, the derived aerosol particles masses for each bin representing the respective MOUDI stage are summed to yield TPM per impaction stage. We used the combined errors presented in Fig. 2 per size bin to yield, by application of the root of sum of squares, the uncertainty of the TPM per stage. MOUDI sampling time is accounted for by the $30 \mathrm{~L} \mathrm{~min}^{-1}$ instrument input flow. This finally yields the TPM for each MOUDI stage that can then be compared with the TEP and CSM concentrations per stage.

Below we report the mass ratio of TEP or CSM to TPM for each MOUDI stage and in sum for all stages, i.e. total sampled TEP or CSM over total TPM. The uncertainty of these ratios results from the uncertainties in TEP and CSM measurements and the uncertainties in TPM measurements.

\section{Results and discussions}

\subsection{Ocean Water Characteristics.}

Concentrations of Chl $a$ in subsurface waters collected at $5 \mathrm{~m}$ depth varied by 2 orders of magnitude between $\sim 0.1$ and $2.2 \mu \mathrm{g} / \mathrm{L}$ over the entire cruise area, indicating relatively low algal biomass. The highest mean Chl $a$ levels were recorded at the northernmost station (Sta. 2) and the lowest Chl $a$ levels occurred at Station 4. The relative abundances of the dominant phytoplankton taxa can be estimated based on the relative concentrations of specific taxonomic indicator accessory pigments (Jeffrey et al., 1999). The most commonly found carotenoid pigments within the study region were fucoxanthin, zeaxanthin, 19'-Hexanoyloxyfucoxanthin, 19'-Butanoyloxyfucoxanthin and peridinin (Table 1). These indicate the presence of several major taxonomic groups of phytoplankton. Fucoxanthin, although present in many golden-brown taxa of phytoplankton, is most commonly associated with the presence of diatoms. Zeaxanthin, another accessory pigment common to several classes, indicates high concentrations of cyanobacteria (e.g., Synechococcus sp. and Prochlorococcus sp.) present at all stations (Jeffrey \& Wright, 1997; Goericke \& Repeta, 1992). The compounds 19'-hexanoyloxyfucoxanthin and 19'-butanoyloxyfucoxanthin are indicators of the presence of coccolithophorids and pelagophytes, respectively (Zapata et al., 2004; Jeffrey \& Wright, 1997). Of particular note is the high concentration of peridinin at station 2, indicating that dinoflagellates were a dominant phytoplankton present here (Jeffrey \& Wright, 1997).

SML samples collected by the rotating drum were enriched in bacteria compared to subsurface waters at both Stas. 1 and 2, but not at Sta. 5 where subsurface bacterial numbers were the lowest (Fig. 5). Phytoplankton numbers may follow a similar pattern to bacterial numbers at Stas. 1 and 2, but data are lacking at Sta. 5. When SML samples were taken using the 
plate method, numbers of phytoplankton were substantially higher in the SML at Stas. 3 and 4, but numbers of bacteria were not.

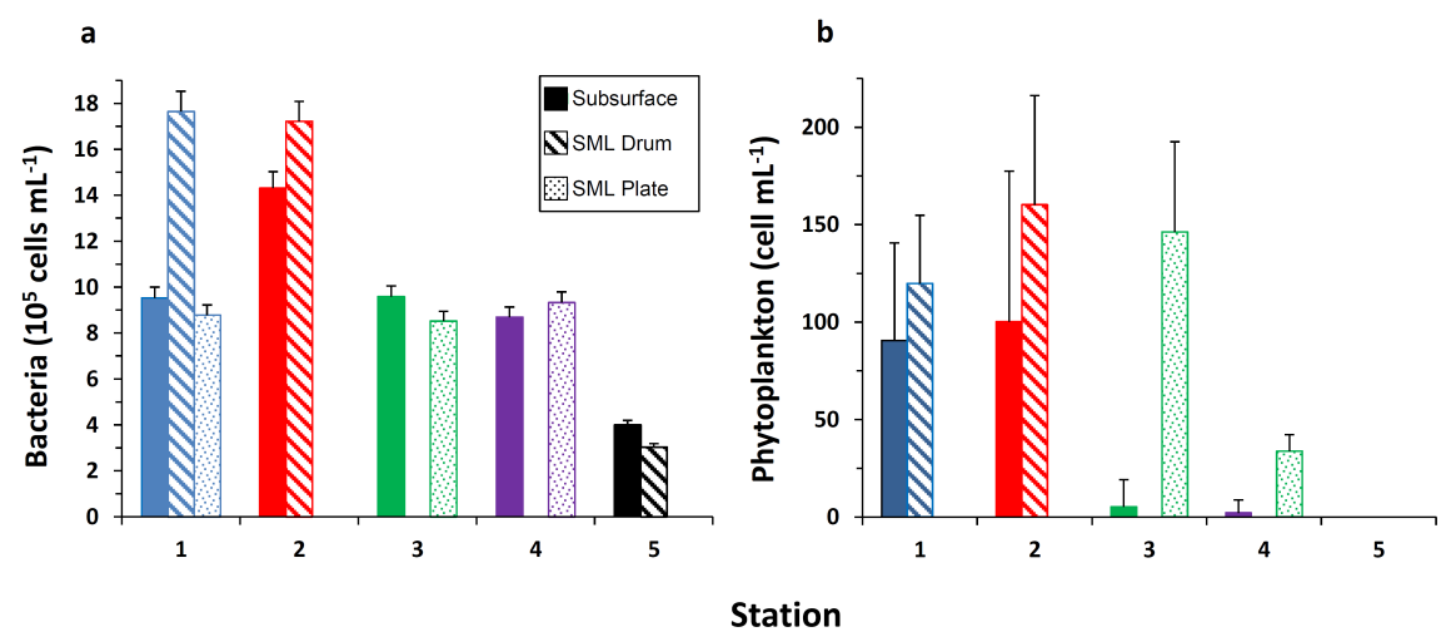

Fig. 5. Bacterial (a) and phytoplankton (b) concentrations in subsurface and SML waters of varying thickness collected by rotating drum and by the plate method. Gaps represent points where conditions precluded sample collection or insufficient sample was available.

Table 3. Particulate organic carbon, particulate organic nitrogen, and dissolved organic carbon in bulk seawater and SML samples. Instrument precision is $5 \%$ for $\mathrm{C}$ and $2 \%$ for $\mathrm{N}$.

\begin{tabular}{|c|c|c|c|c|}
\hline Station & & $\begin{array}{l}\text { DOC } \\
(\mu \mathrm{M})\end{array}$ & $\begin{array}{l}\text { POC } \\
(\mu \mathrm{M})\end{array}$ & $\begin{array}{l}\text { PON } \\
(\mu \mathrm{M})\end{array}$ \\
\hline \multirow[t]{3}{*}{1} & Subsurface & & & \\
\hline & SML drum & 289 & 207 & 10.8 \\
\hline & SML plate & & & \\
\hline \multirow[t]{3}{*}{2} & Subsurface & 134 & 515 & 12.8 \\
\hline & SML drum & 205 & 182 & 8.7 \\
\hline & SML plate & & & \\
\hline \multirow[t]{3}{*}{3} & Subsurface & & & \\
\hline & SML drum & & & \\
\hline & SML plate & 386 & $<2$ & $<1.8$ \\
\hline \multirow[t]{3}{*}{4} & Subsurface & 137 & $<2$ & $<1.8$ \\
\hline & SML drum & & & \\
\hline & SML plate & 140 & $<2$ & $<1.8$ \\
\hline \multirow[t]{3}{*}{5} & Subsurface & 146 & $<2$ & $<1.8$ \\
\hline & SML drum & 185 & $<2$ & $<1.8$ \\
\hline & SML plate & & & \\
\hline
\end{tabular}


Subsurface water chemistry data are available only for Stas. 2, 4, and 5 (Table 3). As expected, subsurface POC and PON levels (Table 2) were highest at Sta. 2, where Chl $a$ levels and microbial numbers were highest (Table 1, Fig. 5). Subsurface water from Stas. 2, 4, and 5, however, had similar DOC levels (Table 2) perhaps reflecting a balance between DOC production and its consumption by heterotrophs.

Although drum-sampled SML water was enriched in bacteria at Sta. 2, POC and PON show no enrichment, but DOC is enriched (Fig. 5 and Table 3). At Sta. 5, where drum-sampled SML water was not enriched in bacteria, POC and PON again showed no enrichment, but DOC levels were slightly higher in the SML. At Sta. 4, where the SML was sampled on shipboard by means of a plate, phytoplankton were enriched in the SML, but levels of bacteria, DOC, POC, and PON showed no difference between SML and subsurface waters. One explanation for these differences is simply the natural variability in water mass characteristics. Apparent differences between stations may also be due to differences in sampling technique with the drum collecting a thinner microlayer than the plate.

It is well known that DOC concentrations, even when collected at the same geographic location and depth below the surface, can vary widely, reflecting small scale temporal and spatial variability. Measured in water collected at $5 \mathrm{~m}$ below the surface during WACS II, DOC concentrations (134-146 $\mu \mathrm{M})$ were higher than measured during the WACS 2012 cruise to the same general area in late August $2012(70-95 \mu \mathrm{M})$. Complicating general comparisons of DOC concentrations in surface oceanic waters with other studies, including many in North Atlantic and Sargasso Sea waters, is the fact that the definition of 'surface' waters which can range from the top 50 to $100 \mathrm{~m}$ (Hansell et. al., 2001) to $2 \mathrm{~m}$ (Carlson, 1983; Alldredge, 2000), $5 \mathrm{~m}$ (Quinn et al., 2014, this study), or $10 \mathrm{~m}$ (Hedges et al., 1993).

TEP and CSM measurements were carried out at Stas. 1, 2, and 5 (Fig. 6) where the SML was collected by the rotating drum sampler. Subsurface TEP values were typical for open ocean waters (see e.g. Bar-Zeev, 2015). The data suggest that the SML at Stas. 1 and 2 was considerably enriched in TEP. A sample collected by the plate method at Sta. 1 also showed TEP enrichment, but to a lesser degree, which would be expected given that the glass plate samples a 20-150 $\mu \mathrm{m}$ thick layer, while the drum sampler collects the upper $50 \mu \mathrm{m}$ (Cunliffe et al., 2013). CSM was enriched in the SML at Sta. 2, but to a lesser extent than TEP.

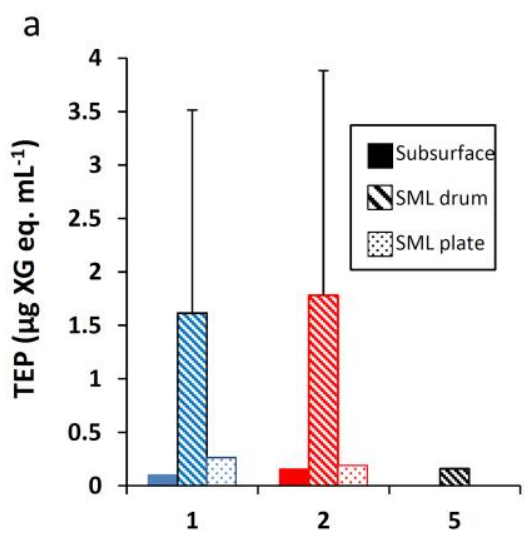

b

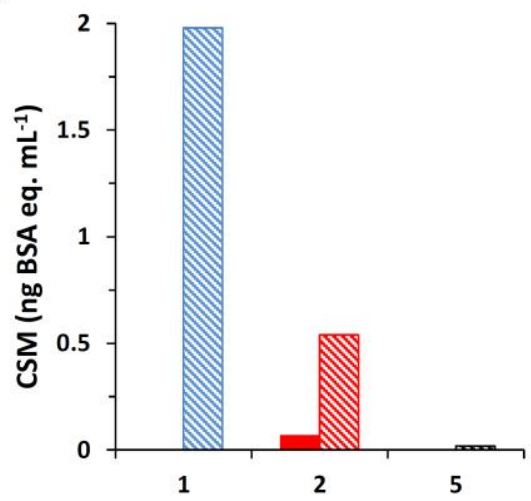

Station 
Fig. 6. Concentrations of (a) TEP and (b) CSM in subsurface and SML waters for stations in cruise area. Stations 3 and 4 are not shown since no data are available. Error bars for TEP data represent standard deviations of triplicate samples. CSM data is for one sample each. Gaps represent points where conditions precluded sample collection.

\subsection{Aerosol Number and Mass}

The primary mode diameter of the number size distributions for Sea Sweep generated aerosol particles averaged over the corresponding period of MOUDI aerosol collection varied very little between stations peaking around $100 \mathrm{~nm}$ (60\% RH) (Fig. 2), reflecting the frit size of the diffusion stones used to generate the sea spray (Bates et al., 2012). Particle number concentrations recorded for the ambient air collected at Station 2/3 averaged $263 \pm 29$ particles $\mathrm{cm}^{-3}$, a value similar to data reported for background marine conditions of 200-300 particles $\mathrm{cm}^{-3}$ in subtropical and equatorial regions (e.g. Covert et al., 1996; Quinn et al., 2002; Bates et al., 2002).

\subsection{Particulate TEP and CSM}

The size fractionated mass of TEP and CSM derived from MOUDI relative to corresponding size fractionated TPM derived from Sea Sweep and ambient air are shown in Figs. 7 and 8, respectively. Note that these are total mass values per stage based on the total sampled air volume at each station. Highest SSA mass concentrations sampled by MOUDI are found for supermicron particle sizes. The highest concentrations of TEP across the different stations are not as clear but in most cases also coincide with supermicron particles, however, their variation

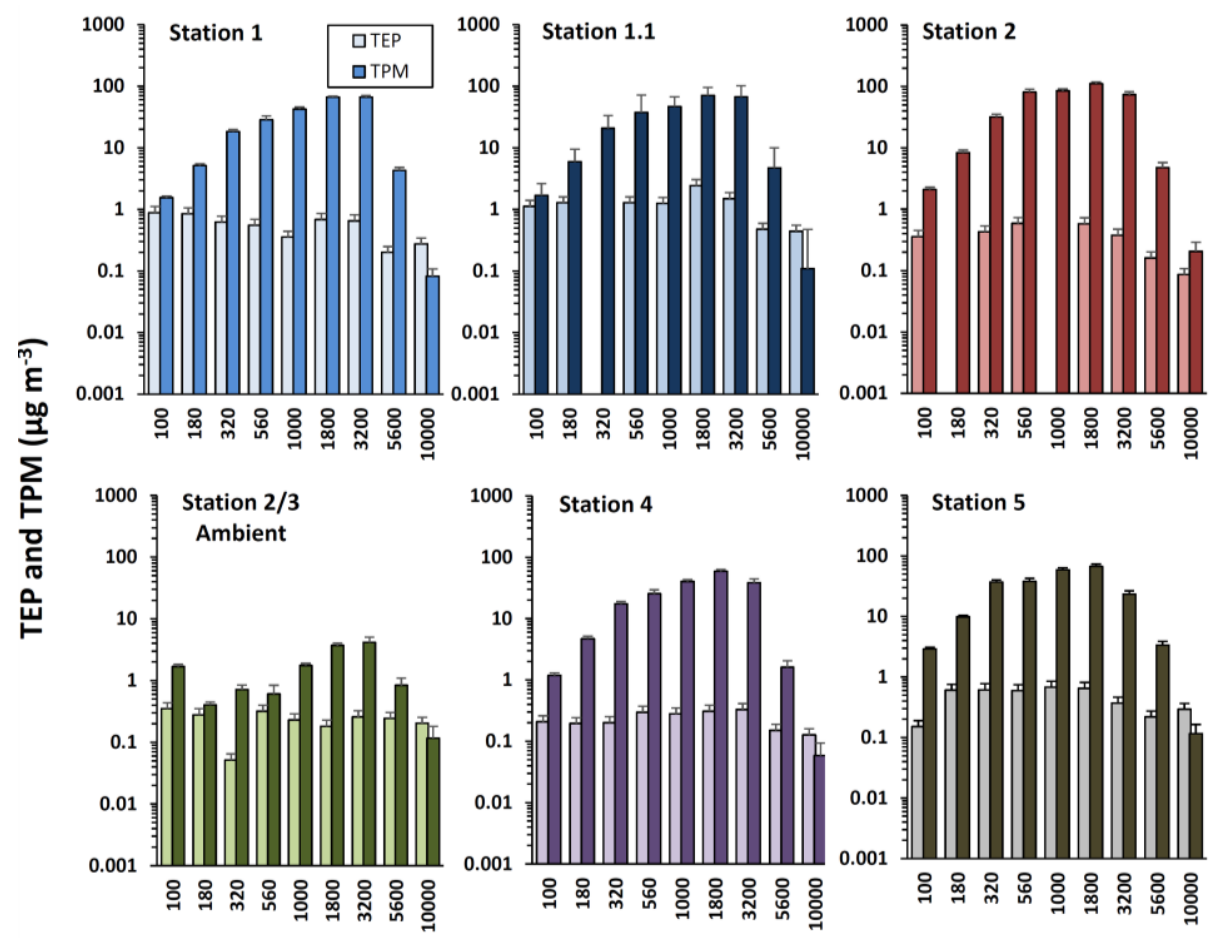

Aerodynamic Particle Diameter (nm) 
Fig. 7. Airborne TEP mass and corresponding TPM for each MOUDI stage collected from Sea Sweep generated SSA and ambient air (Station 2/3). TEP values are the mean of 2 replicates. Error for TEP measurements is $\sim 25 \%$ and error for TPM data represents the total uncertainty due to natural variability and counting statistics. The absence of data means that TEP values were below detection $\left(T E P^{\text {sample }}-T E P^{\text {blank }} \approx 0\right)$.

is much less compared to TPM. In general, TEP mass per stage is always much lower than corresponding TPM except for the largest particles collected by MOUDI (> 10,000 nm), where TPM is underestimated due to the limitation of sampled maximum particle size by APS measurements.
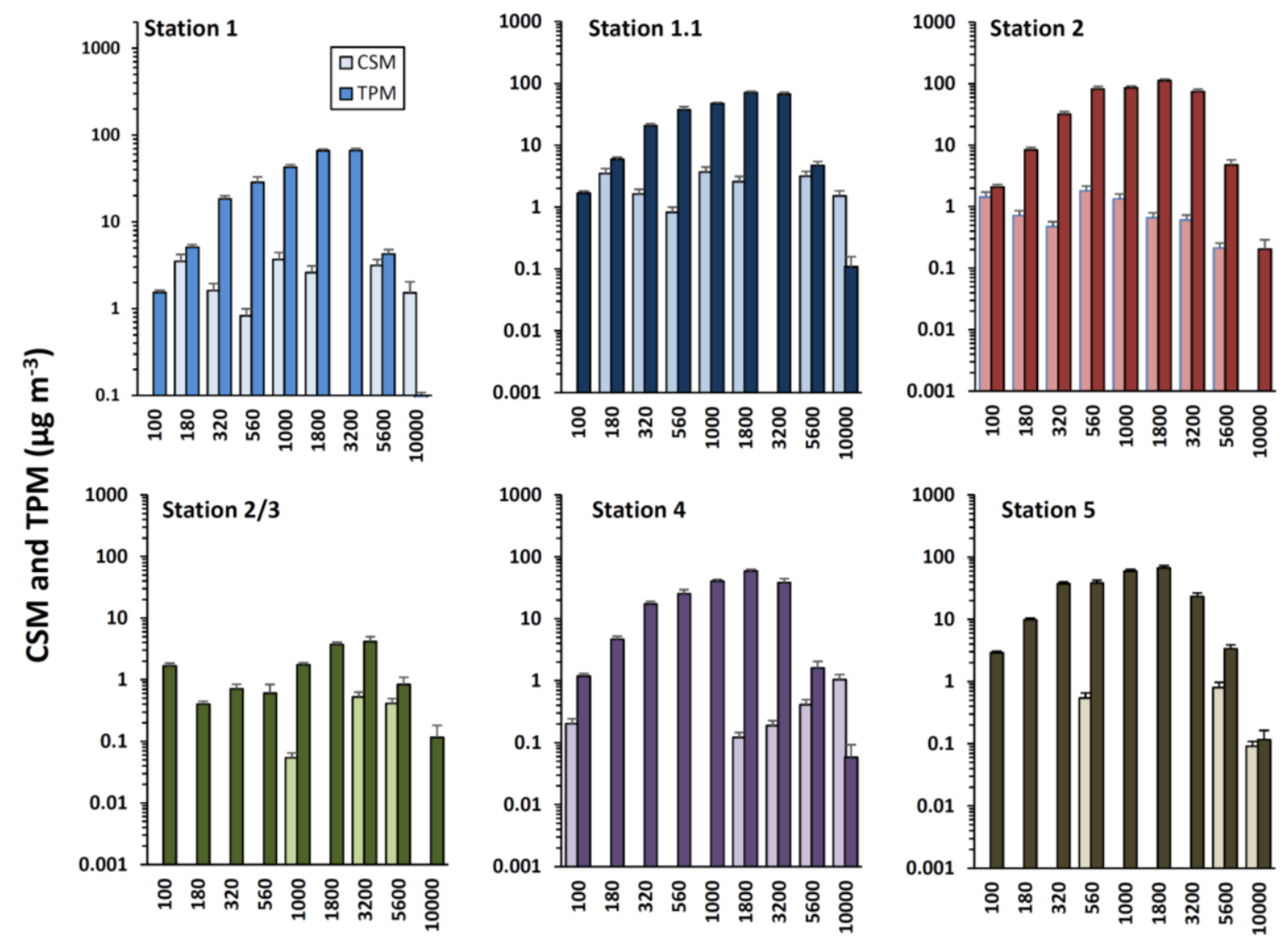

\section{Aerodynamic Particle Diameter (nm)}

Fig. 8. Airborne CSM mass and corresponding TPM collected by MOUDI for each stage from all Sea Sweep stations and ambient air (Sta. 2/3). Error for CSM measurements is $\sim 20 \%$. The TPM data are the same as in Fig. 7. The absence of data means that CSM values were below detection $\left(C S M^{\text {sample }}-C S M^{\text {blank }} \approx 0\right)$. 
To determine the fraction of TEP and CSM mass relative to TPM in Sea Sweep generated SSA and ambient aerosol particles, the TEP or CSM concentration at each MOUDI14stage was divided by the TPM for the corresponding size range (Figs. 9 and 10). The uncertainty of the mass ratio is derived from the sum of the relative errors associated with TEP or CSM and TPM. As explained above, the higher mass ratios of TEP and CSM in particles > 10,000 nm is likely artificial, since not all of these particles are sampled by the APS, implying that TPM mass for this MOUDI stage is underestimated. It should also be remembered that the amounts of TEP and CSM are expressed as equivalent masses of XG or BSA, and that differences in chemical composition of marine polymeric gels might cause them to respond differently to staining, resulting in additional uncertainty, likely giving the lower limits for TEP and CSM masses and thus concentrations. Finally, differences in the viscosity of SSA and ambient particles could potentially influence their properties and therefore adhesion probability in the MOUDI influencing their stage distribution. For example, if the ambient aerosol particles had higher viscosity than those collected from the Sea Sweep, they would have been more prone to bouncing and therefore likely to be accumulated on MOUDI stages with smaller cut-point diameters (e.g. Marple et al., 1991; Ivosevic et al., 2006).
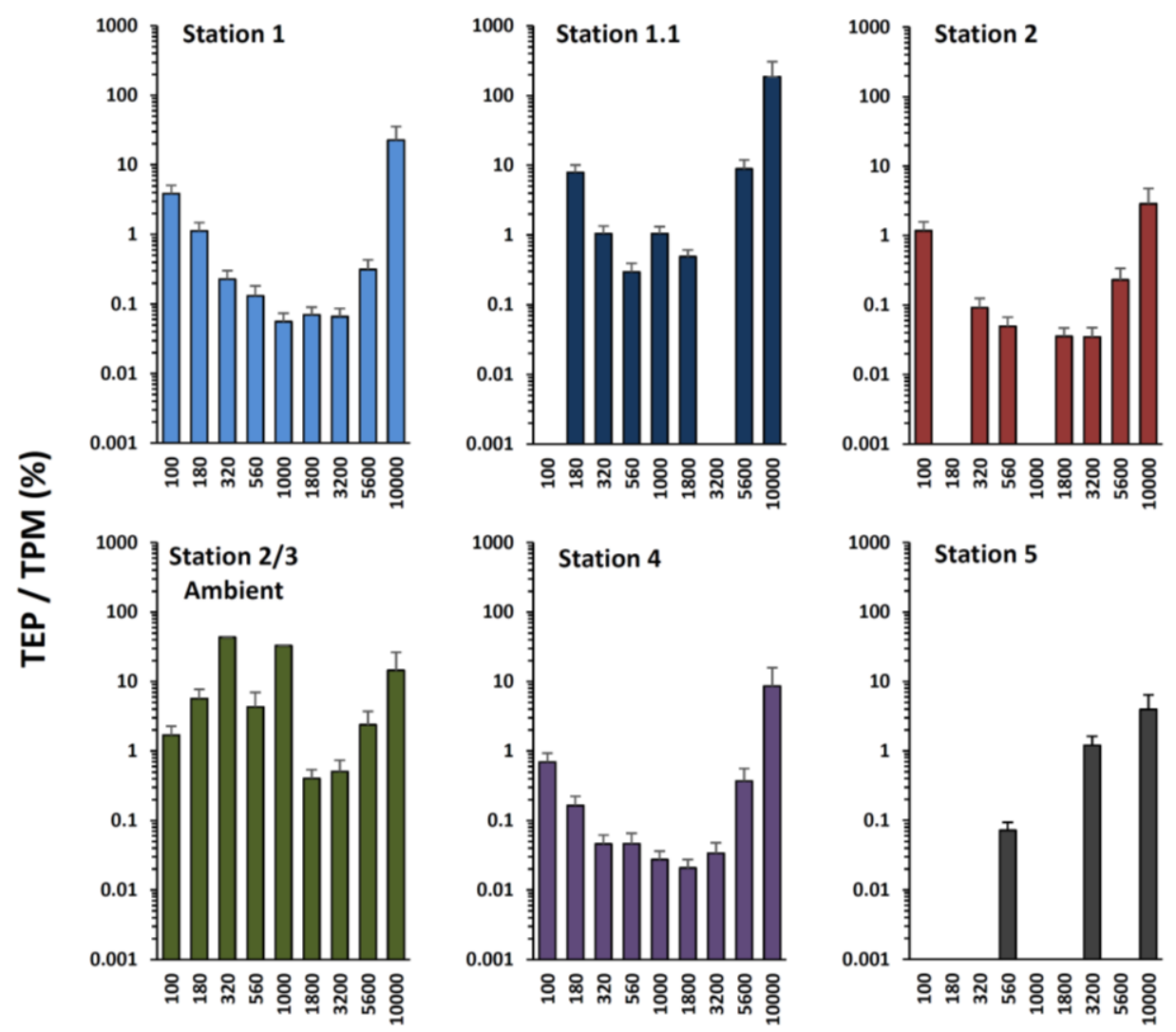

\section{Aerodynamic Particle Diameter (nm)}

Fig. 9. Size fractionated TEP mass concentration in TPM at each station from Sea Sweep generated SSA and ambient air Station 2/3. The absence of data means that TEP values were below detection $\left(T E P^{\text {sample }}-T E P^{\text {blank }} \approx 0\right)$. 
The data displayed in Fig. 9 demonstrate that aerosol particles in the submicron size fractions contained more TEP on average than did larger particles. This effective transfer of organic matter into the fine aerosol fraction corroborates earlier findings, of a dramatic increase in organic matter content of smaller particles in nascent sea spray (Middlebrook et al., 1998; Oppo et al., 1999; O’Dowd et al., 2004; Keene et al., 2007; Facchini et al., 2008; Ault et al., 2013; Prather et al., 2015; Quinn et al., 2015). Previous studies found that heating freshly emitted SSA generated at the ocean surface by use of Sea Sweep to $230{ }^{\circ} \mathrm{C}$ only resulted in a $<15 \%$ decrease in particle number concentration (Quinn et al., 2014) and volatilization of $<10 \%$ of the organic carbon (Quinn et al., 2015) which can be attributed to the colloidal nature of the organic carbon components that are present in seawater and their chemical and physical stability (de Gennes and Léger, 1982; Chin et al., 1998; Verdugo et al., 2008.) This is consistent with the thermal stability of polysaccharide- and proteinaceous-rich material until $>250{ }^{\circ} \mathrm{C}$ (Yun and Park, 2003) and > $280{ }^{\circ} \mathrm{C}$ (White, 1984; Creighton, 1993), respectively. Estimates of TEP content in the smallest particles were high at all stations including the ambient air sample (Fig. 9). The elevated TEP for supermicron particles sizes of $>5600 \mathrm{~nm}$ could reflect the aerosolization of TEP attached to phytoplankton cells or fragments of frustules. Such particles were observed previously in Arctic air samples (e.g. Leck and Bigg, 1999 and Bigg and Leck, 2001) and were similar to particles found in the SML between ice floes (Bigg et al. 2004; Leck et al., 2005). On the other hand, although nanogels are the most abundant in seawater, multiple annealing steps and mixing of gels with longer undegraded polymers produce larger and more stable gels (Passow, 2000).
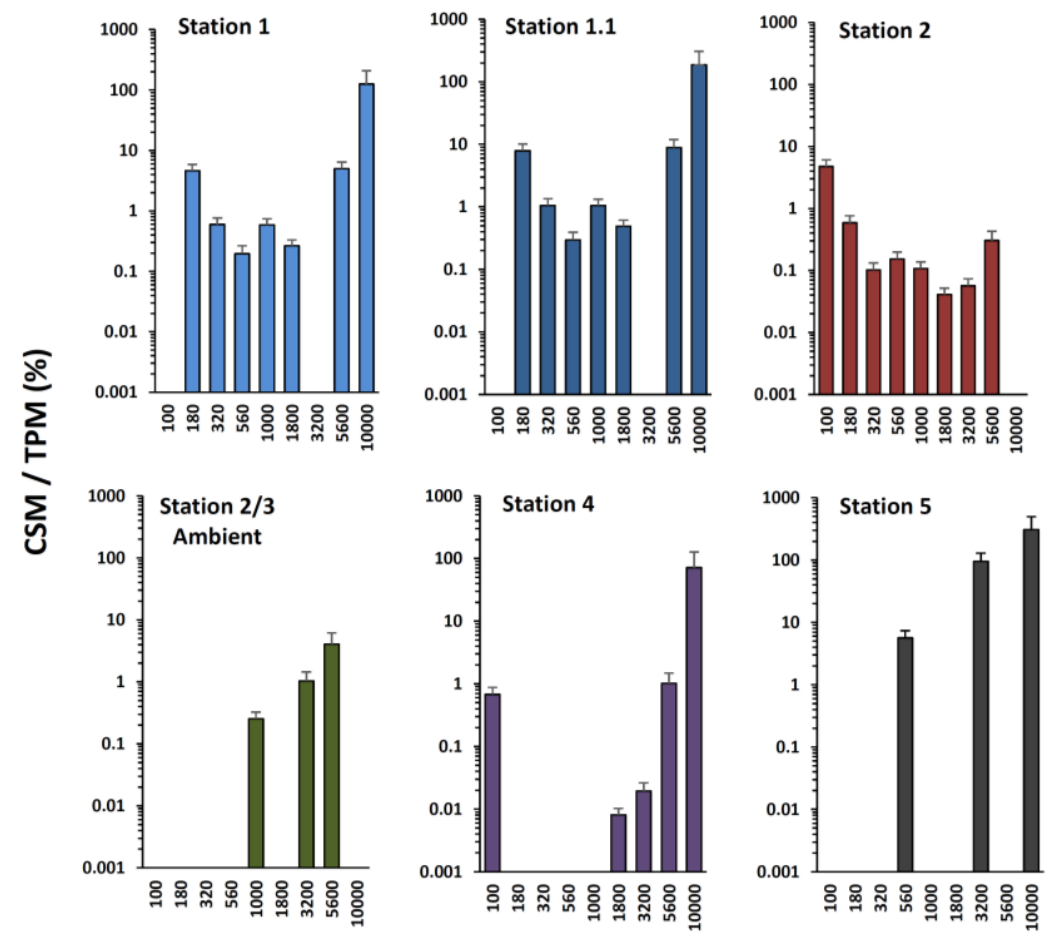

Aerodynamic Particle Diameter (nm)

Fig. 10. Size fractionated CSM mass over TPM at each station from Sea Sweep generated SSA and ambient air Station 2/3. The absence of data means that CSM values were below detection $\left(C S M^{\text {sample }}-C S M^{\text {blank }} \approx 0\right)$. 
Figure 10 shows the particle size-resolved mass ratio of protein-rich CSM to TPM generated by the Sea Sweep and collected from the ambient air. Like TEP-containing particles, CSM ranges in size from a few $\mathrm{nm}$ (nanogels) to a few microns (microgels) (Verdugo 2012). One explanation for the presence of high CSM mass in larger aerosol particles might be that large CSM-containing particles (i.e. gels) in surface waters may be more stable relative to small ones. In fact, this matches with observations that in the SML, CSM generally includes bigger particles than TEP (e.g. Galgani and Engel, 2013). Observations of higher bacterial densities associated with CSM compared with TEP (Berman and Viner-Mozzini, 2001) introduce the possibility that the protein-rich gel particles are larger because they include bacteria or bacterial fragments which average 1-3 $\mu \mathrm{m}$ in size. There is little information about CSM production by different phytoplankton species or about how algal growth phase or bacterial abundance influence CSM concentrations and size, but our findings are consistent with observations that TEP and CSM are different particles with different characteristics and behavior in surface waters, and may be differently affected by the nature of the dominant phytoplankton group and the activities of associated bacteria (Long and Azam, 1996; Berman and Viner-Mozzini, 2001; Cisternas-Novoa et al., 2015). These differences may also affect the efficiency with which they are aerosolized.

The enrichment trend for smaller particles in this case is not as clear as for TEP since in some instances CSM could not be detected. This may imply that the concentration of CSM in general is lower in SSA compared to TEP. As in the case of TEP, most stations demonstrate a strong enrichment of CSM in supermicron size particles. Proteinaceous materials include cells and cell fragments, and thus the elevated CSM values at larger particles sizes could be due to aerosolization of phytoplankton or bacterial cells or fragments. Alternately or additionally, this could be related to the observed greater stability of Coomassie stainable gels compared to TEP in surface waters (e.g. Passow, 2000). This difference in behavior might enable the persistence and availability for aerosolization of relatively large CSM-containing particles.
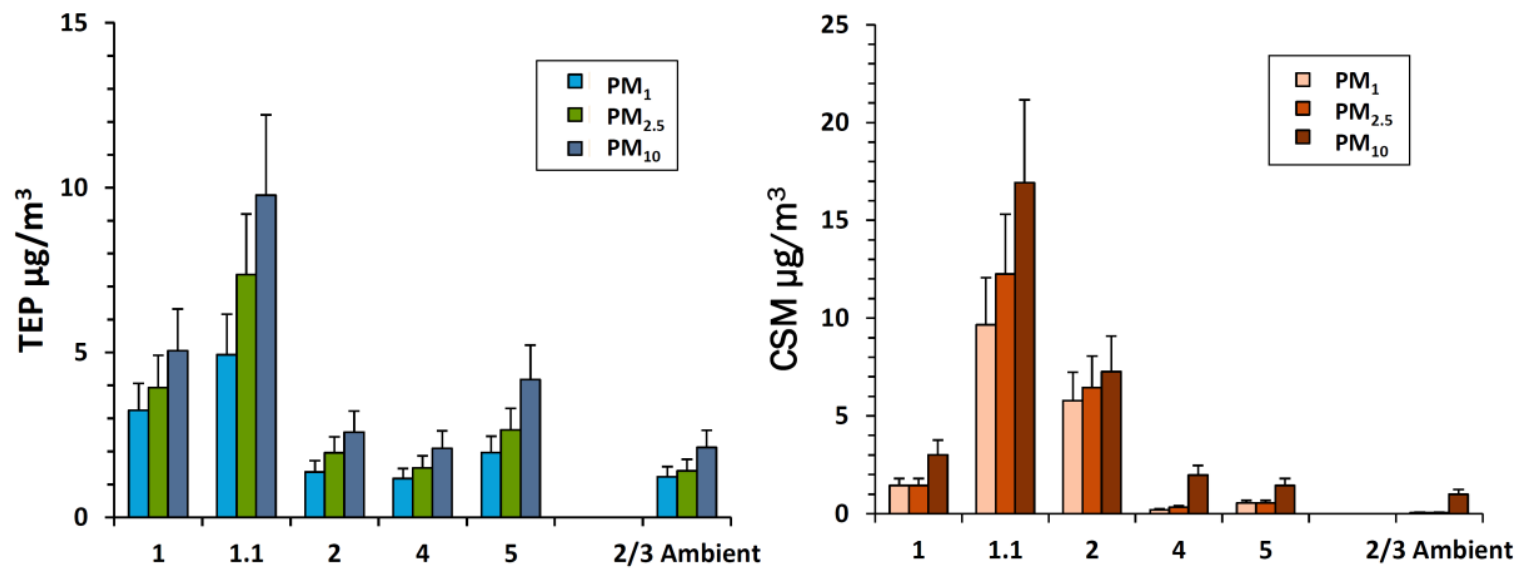

Station

Fig. 11. Particulate mass $\mathrm{PM}_{1}, \mathrm{PM}_{2.5}$ and $\mathrm{PM}_{10}$ of TEP and CSM generated by Sea Sweep and collected in the ambient air sample. 
Figure 11 presents the estimated total TEP and CSM concentrations associated with $\mathrm{PM}_{1}$, $\mathrm{PM}_{2.5}$ and $\mathrm{PM}_{10}$ derived from particles impacted onto MOUDI stages. As noted earlier, comparison of absolute concentrations between stations cannot be done due to the manner in which the Sea Sweep operates. TEP and CSM concentrations are given for both Sea Sweep and the ambient air samples to demonstrate the capability of our novel method. Concentrations of TEP for Sea Sweep generated SSA ranged from 1.2 to $4.9 \mu \mathrm{g} \mathrm{m}^{-3}$ for $\mathrm{PM}_{1,1.5}$ to $7.4 \mu \mathrm{g} \mathrm{m}^{-3}$ for $\mathrm{PM}_{2.5}$ and 2.1 to $9.8 \mu \mathrm{g} \mathrm{m}^{-3}$ for $\mathrm{PM}_{10}$. In ambient particles, TEP measured 1.2. 1.4 and $2.1 \mu \mathrm{g} \mathrm{m}^{-3}$ for $\mathrm{PM}_{1}, \mathrm{PM}_{2.5}$ and $\mathrm{PM}_{10}$, respectively. CSM concentrations for Sea Sweep generated SSA ranged between 0.2 to $9.7 \mu \mathrm{g} \mathrm{m}^{-3}$ for $\mathrm{PM}_{1}, 0.32$ to $12.2 \mu \mathrm{g} \mathrm{m}^{-3}$ for $\mathrm{PM}_{2.5}$ and 1.4 to $16.9 \mu \mathrm{g} \mathrm{m}^{-3}$ for $\mathrm{PM}_{10}$. In ambient particles, CSM measured $0.05,0.05$ and $1.0 \mu \mathrm{g} \mathrm{m}{ }^{-3}$ for $\mathrm{PM}_{1}, \mathrm{PM}_{2.5}$ and $\mathrm{PM}_{10}$, respectively.

While a large percentage of TEP and CSM particles relative to the total sampled aerosol particle mass were in sizes $<300 \mathrm{~nm}$, relatively large TEP and CSM particles were also collected including some $>1,000 \mathrm{~nm}$ on MOUDI stage 1 (Figs. 7, and 8). If these large TEP and CSM particles are phytoplankton or bacterial cells or their fragments, they could represent a source of efficient ice nucleating particles (Knopf 2011, Alpert 2011a, b, Pandey et al. 2016). Finally, the ambient particles were collected from an air mass that had been over relatively more productive waters than the waters sampled by the Sea Sweep and presumably carried organic rich particles resulting in enhanced TEP and CMS mass fractions (Fig. 1). Clearly these possibilities suggest the need for additional studies, however, the enrichment of organic rich particles in the finest aerosol sizes is consistent with the findings of Facchini et al. (2008) who showed that microgel organic compounds identified as lipopolysaccharides were preferentially transferred to the submicron aerosol size fraction during bubble bursting over ocean waters of moderate productivity.

\subsubsection{Summary and Conclusions.}

The chemical composition and quantity of organic constituents of a given water mass can be expected to directly influence nascent sea spray. In contrast, the characteristics of ambient aerosols will vary regionally, with properties highly dependent on local meteorological conditions and related air mass back trajectories. The HYSPLIT model back trajectories presented in Fig. 1 clearly show that the air masses during the sampling time were from the northeast over open ocean waters and had experienced only minimal continental influence. The altitude dependence of the trajectories shows that all air masses had been in the boundary layer prior to arrival at the sampling location. SeaWIFS images (Fig. 1b) indicate that waters along the trajectory were productive, potentially enhancing the concentration of organic-rich submicron size particles in the ambient air mass sampled at Sta. 2/3.

The spatial and temporal variation in numbers and metabolic activities of phytoplankton and bacteria in ocean surface waters may be expected to disproportionately impact the physicochemical and biological properties of the SML, where various components are typically present at higher concentrations than in subsurface waters (Bar-Zeev et al., 2012; Cunliffe et al., 2013). Indeed, in this study we found that both TEP and CSM were enriched in the SML waters of Stas. 1 and 2 with enrichment factor (EF) values of $12.4 \pm 3.6$ for TEP and $11.1 \pm 6.6$ for CSM. The similarity in EF values is intriguing given the recent study by Cisternas-Novoa et al. (2015) which demonstrates that at least in subsurface waters exopolymer particles of polysaccharidic composition are a separate particle type and therefore might not be expected to 
behave the same as particles of proteinaceous composition within the pool of organic matter. Aspects of the behavior of protein-containing gel material in the SML, including the exact association with TEP and the conditions controlling particle formation, are not clear (Engel, 2009). However, our data are consistent with previous findings of enhanced CSM, protein, and amino acid concentrations in SML samples (Galgani and Engel, 2013; Kuznetsova et al., 2005; Kuznetsova and Lee, 2001; Mari and Burd, 1998) and Coomassie Stainable Particle (CSP) abundances (Galgani et al., 2016).

The enhanced concentrations of both TEP and CSM in the SML and strong enrichment in submicron size of aerosolized particles is highly relevant given recent findings linking marine organic material to ice nucleating particles (INPs) in the atmosphere (e.g. Wilson et al., 2015; Ladino et al., 2015, Knopf et al., 2014). A considerable population of INPs examined by Wilson et al. (2015) from SML material including some collected during the WACS II cruise was smaller than $0.2 \mu \mathrm{m}$ and therefore likely to consist largely of exudates from phytoplankton and other microorganisms. After heating to $100^{\circ} \mathrm{C}$, some of the samples had significantly reduced ice forming activity consistent with the denaturation of proteins and loss of rheological polymer properties and morphological structure of polysaccharides (e.g. Rederstorff et al., 2011) suggesting that the ice nucleating activity was associated with these organic compounds.

Predicting aerosol quantity, size distribution, and composition from water quality parameters is currently problematic. The chemical composition as well as relative concentration of individual constituents affects aerosolization of particles from the SML. Surface-active substances stabilize microlayers (e.g. Wurl et al., 2009; Long et al., 2014), impact the size distribution of SSA (e.g. Sellegri et al., 2006; Fuentes et al., 2010;), and can alter the concentration and physicochemical properties of the aerosolized organic material (e.g. O'Dowd et al., 2004; Yoon et al., 2007; Vignati et al., 2010; Russell et al., 2010; Fuentes et al., 2011; Cunliffe et al., 2012; Gantt and Meskhidze, 2013). While phytoplankton community structure and biomass can be related to Chl $a$ levels in ocean surface waters, these levels track only a small fraction of the ocean carbon pool and do not necessarily predict levels of DOM in surface waters (e.g. Quinn et al., 2014). Chl $a$ also appears to be an imperfect predictor of SSA organic enrichment (e.g. Rinaldi et al., 2013; Quinn et al., 2014) which is confirmed by our results from stations where SSA was Sea Sweep generated. During WACS I, Chl $a$ biomass averaged $7.1 \pm$ $2.2 \mu \mathrm{g} \mathrm{L}^{-1}$ and DOC averaged $89 \pm 3 \mu \mathrm{M}\left(1.068 \pm 0.036 \mathrm{mg} \mathrm{L}^{-1}\right)$ at a station off Georges Banks in productive waters, whereas Chl $a$ averaged $0.03 \pm 0.06 \mu \mathrm{g} \mathrm{L}^{-1}$ and DOC averaged $72 \pm 3 \mu \mathrm{M}$ at a station in oligotrophic waters off Bermuda. This mismatch was also observed during the WACS II cruise, during which $2.2 \mu \mathrm{g} \mathrm{L}^{-1} \mathrm{Chl} a$ and $63 \mu \mathrm{M}$ DOC were seen at Station 2 surface waters, while $0.1 \mu \mathrm{g} \mathrm{L}^{-1} \mathrm{Chl} a$ and $65 \mu \mathrm{M}$ DOC were seen at Sta. 4. (Table 1). Nevertheless, our findings agree with those of Quinn and colleagues during the WACS I cruise (Quinn et al., 2014) and previously during the CalNEX cruise along the California coast (Bates et al, 2012) in that, that regardless of sampling location, organic enrichment occurs in all particle sizes, with the smallest particles $(<180 \mathrm{~nm})$ being most enriched. Additionally, we find that this enrichment is apparent whether SSA are collected as nascent sea spray or as ambient air. Regarding the ambient sample, we do not know how the particles collected were generated (i.e. wave, wind, or combination) and their exact origin. What we do know is that during the previous week air passed over the highly productive continental shelf region of Georges Bank and briefly over Newfoundland, both ideal sources of aerosolized particles including both protein-rich and polysaccharide-rich ones. While the possible contribution to the aerosol mass in the ambient sample by condensing secondary organic material cannot be completely ruled out, the peak 
absorbance of aged SOA material is at lower wave lengths (Laskin et al., 2015, Chen et al., 2016) than the ones for applied Alcian Blue and Comassie Brilliant Blue dyes. Furthermore, it is not known whether aged SOA material can be stained by either of these dyes. Regardless of the limitations, the size fractionated measurements of polysaccharide and proteinaceous organic components of SSA collected directly as nascent sea spray and as ambient aerosol presented here, represent a novel method to infer the relationship between marine biogenic and biological material and airborne particulate matter.

Although TEP and CSM concentrations can only provide information about a portion of the particulate organic matter pool in the ambient air together they could make up at least half of the organic composition and possibly greater depending on conditions in surface waters. Temporal variability in biological activity is clearly reflected in submicron organic aerosol concentrations. For example, $\mathrm{PM}_{2.5}$ organic aerosol concentrations measured over N.E. Atlantic coastal waters for a 4 week late summer period varied between 0.36 and $1.0 \mu \mathrm{g} \mathrm{m}^{-3}$ but reached $3.8 \mu \mathrm{g} \mathrm{m}^{-3}$ (Ovadnevaite et al., 2011). Similarly, seasonal organic mass concentrations of SSA PM 2.5 off Mace Head reported by Ovadnevaite (et al., 2014) varied from $0.025-0.4 \mu \mathrm{g} \mathrm{m}^{-3}$ but during a period of high biological activity reached $2.46 \mu \mathrm{g} \mathrm{m}^{-3}$. During WACSII the ambient air sample $\mathrm{PM}_{2.5}$ TEP and CSM concentrations were within this range measuring $1.41 \pm 0.35$ and $0.054 \pm$ $0.013 \mu \mathrm{g} \mathrm{m}^{-3}$, respectively. In more remote open ocean regions of, e.g., the North Atlantic and Arctic, organic aerosol concentrations can be similar to our data. Although not measured for $\mathrm{PM}_{2.5}$, for $\mathrm{PM}_{1}$ the organic component of SSA comprised largely of saccharides and was found to vary between $0.1-0.4 \mu \mathrm{g} \mathrm{m}^{-3}$ with measurements as high as $0.73 \pm 0.37 \mu \mathrm{g} \mathrm{m}^{-3}$ (Russell et al., 2010). In comparison $\mathrm{PM}_{1}$ TEP at ambient air Sta. 2/3 collected over moderately productive surface waters averaged $1.23 \pm 0.31 \mathrm{\mu g} \mathrm{m}^{-3}$.

Finally, it is well known that primary biological aerosol particles (PBAPs) are an important subset of atmospheric aerosol (e.g. Jaenicke, 2005; Després et al., 2012) and that the marine environment acts as an important source. Our novel method of determining the mass fraction of TEP and CSM in the total aerosol particles mass may be useful for complementary determination of polysaccharidic and proteinaceous components of airborne organic matter, in general, including the accumulation and coarse mode for particles up to $18 \mu \mathrm{m}$ in diameter. In particular, measurements of CSM would allow comparative studies with fluorescent based detection techniques to estimate the total biological particulate fraction in environmental aerosol samples which target tryptophan, the dominant fluorophore in proteins (e.g. Huffman et al., 2010; Pöhlker et al., 2012; Bianco et al., 2016).

\section{Acknowledgements}

The authors thank the scientists and crew of the R/V Knorr, for assistance with sample collection and for sharing data. Anna Lubitz provided assistance in the laboratory and David Hirschberg made DOC, POC, and PON measurements. The authors gratefully acknowledge the NOAA Air Resources Laboratory (ARL) for the provision of the HYSPLIT transport and dispersion model and/or READY website (http://www.ready.noaa.gov). NASA Ocean Biology Distributed Active Archive Center (OB.DAAC) provided Sea-viewing Wide Field-of-view Sensor (SeaWIFS) Ocean Color Data, NASA OB. DAAC. http://doi.org/10.5067/ORBVIEW-

2/SEAWIFS_OC.2014.0. Accessed on 2015/09/14. Funding was provided by National Science Foundation grant AGS-1232203 and the European Research Council (ERC, 240449 ICE) and the Natural Environment Research Council (NERC, NE/K004417/1). This is PMEL contribution number 4582. 


\section{References}

Agogue, H., E. O. Casamayor, F. Joux, I. Obernosterer, C. Dupuy, F. Lantoine, P. Catala, M. G. Weinbauer, T. Reinthaler, G. J. Herndl, and P. Lebaron, 2004: Comparison of samplers for the biological characterization of the sea surface microlayer. Limnology \& OceanographyMethods, 2, 213-225.

Alldredge, A.L. 2000: Interstitial dissolved organic carbon (DOC) concentrations within sinking marine aggregates and their potential contribution to carbon flux. Limnology \& Oceanography, 45, 1245-1253.

Alldredge, A. L., U. Passow, and B. E. Logan, 1993: The Abundance and Significance of a Class of Large, Transparent Organic Particles in the ocean. Deep-Sea Research Part IOceanographic Research Papers, 40, 1131-1140.

Alpert, P. A., Aller, J. Y., and D. A. Knopf, 2011a: Ice nucleation from aqueous $\mathrm{NaCl}$ droplets with and without marine diatoms, Atmospheric Chemistry Physics, 11, 5539-5555, doi: 10.5194/acp-11-5539-2011.

Alpert, P. A., Aller, J. Y., and D. A. Knopf, 2011b: Initiation of the Ice Phase by Marine Biogenic Surfaces in Supersaturated Gas and Supercooled Aqueous Phases. Special issue "Physics and Chemistry of Water and Ice" of Physical Chemistry Chemical Physics, 13, 19882-19894, doi: 10.1039/C1CP21844A.

Alpert, P. A., Kilthau, W. P., Bothe, D. W., Radway, J. C., Aller, J. Y., and D. A. Knopf, 2015: The influence of marine microbial activities on aerosol production: A laboratory mesocosm study, Journal of Geophysical Research Atmospheres, 120, 17, 8841-8860, doi:1 $0.1002 / 2015 J D 023469$.

Andreae, M. O., 2009: Natural and anthropogenic aerosols and their effects on clouds, precipitation and climate. Geochimica Et Cosmochimica Acta, 73, A42-A42.

Ault, A. P., and Moffet, R. C., Baltrusaitis, J., Collins, D. B., Ruppel, M. J., and Coauthors, 2013: Size-Dependent Changes in Sea Spray Aerosol Composition and Properties with Different Seawater Conditions. Environmental Science \& Technology, 47, 5603-5612, doi: 10.1021/es400416g

Bar-Zeev, E., I. Berman-Frank, O. Girshevitz, and T. Berman, 2012: Revised paradigm of aquatic biofilm formation facilitated by microgel transparent exopolymer particles. Proceedings of the National Academy of Sciences of the United States of America, 109, 9119-9124, doi:10.1073/pnas.1203708109.

Bar-Zeev, E., U. Passow, S. R.-V. Castrillon, and M. Elimelech, 2015: Transparent Exopolymer Particles: From Aquatic Environments and Engineered Systems to Membrane Biofouling. Environmental Science \& Technology, 49, 691-707, doi: 10.1021/es5041738

Bates, T. S., P. K. Quinn, A. A. Frossard, L. M. Russell, J. Hakala, T. Petäjä, M. Kulmala, D. S. Covert, C. D. Cappa, s.-M. Li, K. L. Hayden, I. Nuaaman, R. McLaren, P. Massoli, M. R. Canagaratna, T. B. Onasch, D. Sueper, D. R. Worsnop, and W. C. Keene, 2012: Measurements of ocean derived aerosol off the coast of California. Journal of Geophysical Research-Atmospheres, 117, D00V15, doi: 10.1029/2012JD017588.

Berman, T., and Y. Viner-Mozzini, 2001: Abundance and characteristics of polysaccharide and proteinaceous particles in Lake Kinneret. Aquatic Microbial Ecology, 24, 255-264.

Bianco, A., M. Passananti, L. Deguillaume, G. Mailhot, and B. Marcello, 2016: Tryptophan and tryptophan-like substances in cloud water: Occurrence and photochemical fate. Atmospheric 
Environment, 137, 53-61. Bigg, E. K., 2007: Sources, nature and influence on climate of marine airborne particles. Environmental Chemistry, 4, 155-161.

Bigg, E. K., and C. Leck, 2001: Properties of the aerosol over the central Arctic Ocean. Journal of Geophysical Research-Atmospheres, 106, 32101-32109.

Bigg, E. K., and C. Leck, 2008: The composition of fragments of bubbles bursting at the ocean surface. Journal of Geophysical Research-Atmospheres, 113, D11209, doi: 10.1029/2007JD009078.

Bigg, E. K., C. Leck, and L. Tranvik, 2004: Particulates of the surface microlayer of open water in the central Arctic Ocean in summer. Marine Chemistry, 91, 131-141.

Blanchard, D. C., 1964: Sea-to-air transport of surface active material. Science, 146, 396-397.

Burrows, S. M., Ogunro, O., Frossard, A. A., Russell, L. M., Rasch, P. J., and S. M. Elliott, 2014: A physically based framework for modeling the organic fractionation of sea spray aerosol from bubble film Langmuir equilibria. Atmospheric Chemistry and Physics, 14(24), 13601-13629, doi: 10.5194/acp-14-13601-2014

Burrows, S. M., E. Gobrogge, L. Fu, K. Link, S.M. Elliott, H. Wang, and R. Walker, 2016: OCEANFILMS-2: Representing coadsorption of saccharides in marine films and potential impacts on modeled marine aerosol chemistry. Geophysical Research Letters, 43(15), 83068313, doi. 10.1002/2016GL069070.

Carlson, D. J., 1983: Dissolved organic materials in surface microlayers: Temporal and spatial variability and relation to sea state. Limnology \& Oceanography, 28(3), 415-431. Cincinelli, A., A. M. Stortini, L. Checchini, T. Martellini, M. Del Bubba, and L. Lepri, 2005: Enrichment of organic pollutants in the sea surface microlayer (SML) at Terra Nova Bay, Antarctica: influence of SML on superfacial snow composition. Journal of Environmental Monitoring, 7, 1305-1312.

Ceburnis, D., C. D. O’Dowd, G. S. Jennings, M. C. Facchini, L. Embilico, S. Decesari, S. Fuzzi, and J. Sakalys, 2008: Marine aerosol chemistry gradients: Elucidating primary and secondary processes and fluxes. Geophysical Research Letters, 35(7), L07804, doi: 10.1029/2008GL033462

Chin, W.-C., M.V. Orellana, and P. Verdugo, 1998: Spontaneous assembly of marine dissolved organic matter into polymer gels. Nature, 391, 568-572.

Cincinelli, A., Stortini, A. M., Checchini, L., Martellini, T., Del Bubba, M., and L. Lepri, 2005: Enrichment of organic pollutants in the sea surface microlayer (SML) at Terra Nova Bay, Antarctica: influence of SML on superfacial snow composition. Journal of Environmental Monitoring, 7(12), 1305-1312.

Cisternas Novoa, C., C. Lee, and A. Engel, 2014: A spectrophotometric, dye-binding assay for determination of Coomassie Blue stainable particles. Limnology \& Oceanography Methods.12, 604-616.

Cisternas-Novoa, C., C. Lee, and A. Engel, 2015: Transparent exopolymer particles (TEP) and Coomassie stainable particles (CSP): Differences between their origin and vertical distributions in the ocean. Marine Chemistry. 175, 56-71, doi: 10.1016/j.marchem.2015.03.009

Claustre, H., Hooker, S. B.,Van Heukelem, L., Berthon, J. F.,Barlow, R., Ras, J.,Sessions, H.,Targa, C.,Thomas, C. S.,van der Linde, D., and J. C. Marty, 2004: An intercomparison of HPLC phytoplankton pigment methods using in situ samples: application to remote sensing and database activities. Marine Chemistry, 85, 41-61. 
Cochran, Richard E.; Laskina, Olga; J., Thilina, A. Lakin, J. Laskin, P. Lin, C.D. Cappa, T. H. Bertram, K A. Prather, V. H. Grassian, and E. A. Stone, 2016: Analysis of Organic Anionic Surfactants in Fine and Coarse Fractions of Freshly Emitted Sea Spray Aerosol. Environmental Science \& Technology 50(5),2477-2486, doi: 10.1021/acs.est.5b04053

Covert, D. S., Kapustin, V. N., Bates, T. S., and P. K.Quinn, 1996: Physical properties of marine boundary layer aerosol particles of the mid-Pacific in relation to sources and meteorological transport. Journal of Geophysical Research-Atmospheres, 101, 6919-6930.

Creighton, T. E., 1993: Proteins: Structures and Molecular Properties (2nd ed.). W H Freeman and Company, New York.

Cunliffe, M., R. C. Upstill-Goddard, and J. C. Murrell, 2011: Microbiology of aquatic surface microlayers. FEMS Microbiology Reviews, 35, 233-246.

Cunliffe, M., and Coauthors, 2013: Sea surface microlayers: A unified physicochemical and biological perspective of the air-ocean interface. Progress in Oceanography, 109, 104-116, doi:10.1016/j.pocean.2012.08.004.

de Gennes, P. G., and L. Léger, 1982: Dynamic of entagled polymer chains. Annual Review Physical Chemistry, 33:49-61. doi: 10.1146/annurev.pc.33.100182.000405

de Leeuw, G., E. L Andreas, M. D. Anguelova, C. W. Fairall, E. R. Lewis, C. O’Dowd, M. Schulz, and S. E. Schwartz, 2011: Production flux of sea spray aerosol. Reviews of Geophysics, 49 RG2001, doi: 10.1029/2010RG000349.

Després, V. R., Huffman, J. A., Burrows, S. M., Hoose, C., Safatov, A. S., Buryak, G. A., Fr"ohlich-Nowoisky, J., Elbert,W., Andreae, M. O., P“oschl, U., and R. Jaenicke, 2012: Primary Biological Aerosol Particles in the Atmosphere: A Review, Tellus Series BChemical and Physical Meteorology, 2012, 64, 15598, doi: 10.3402/tellusb.v64i0.15598.

Draxler, R. R., and G. D. Rolph: HYSPLIT (HYbrid Single-Particle Lagrangian Integrated Trajectory) Model access via NOAA ARL READY Website [Available online at http://ready.arl.noaa.gov/HYSPLIT.php.]

Engel, A., 2009: Determination of Marine Gel Particles. Practical Guidelines for the Analysis of Seawater, CRC Press.

Facchini, M. C., Rinaldi, M., Decesari, S., Carbone, C., Finessi, E., Mircea, M. and Coauthors, 2008: Primary submicron marine aerosol dominated by insoluble organic colloids and aggregates. Geophysical Research Letters, 35 35, L17814, doi:10.1029/2008GL034210.

Frossard, A. A., L. M. Russell, P. Massoli, T. S. Bates, and P. K. Quinn, 2014: Side-by-side comparison of four techniques explains the apparent differences in the organiccomposition of generated and ambient marine aerosol particles. Aerosol Science and Technology, 48(3), v-X, doi:10.1080/02786826.2013.879979.

Fuentes, E., H. Coe, D. Green, and G. McFiggans, 2011: On the impacts of phytoplanktonderived organic matter on the properties of the primary marine aerosol - Part 2: Composition, hygroscopicity and cloud condensation activity. Atmospheric Chemistry and Physics, 11, 2585-2602.

Fuentes, E., H. Coe, D. Green, G. de Leeuw, and G. McFiggans, 2010: On the impacts of phytoplankton-derived organic matter on the properties of the primary marine aerosol - Part 1: Source fluxes. Atmospheric Chemistry and Physics, 10, 9295-9317, doi:10.5194/acp-109295-2010.

Galgani, L. and A. Engel, 2013: Accumulation of Gel Particles in the Sea-Surface Microlayer during an Experimental Study with the Diatom Thalassiosira weissflogii. International Journal of Geosciences, 4, 129-145, doi:10.4236/ijg.2013.41013. 
Galgani, L., J. Piontek, and A. Engel, 2016: Biopolymers form a gelatinous microlayer at the airsea interface when Arctic sea ice melts. Scientific Reports, 6, 29465; doi: 10.1038/srep29465.

Gantt, B., and N. Meskhidze, 2013: The physical and chemical characteristics of marine primary organic aerosol: a review. Atmospheric Chemistry and Physics, 13, 3979-3996.

Gantt, B., N. Meskhidze, M. C. Facchini, M. Rinaldi, D. Ceburnis, and C. O'Dowd, 2011: Wind speed dependent size-resolved parameterization for the organic enrichment of sea spray. Atmospheric Chemistry and Physics, 11, 10525-10555, doi: 10.5194/acp-13-3979-2013.

Gao, Q., C. Leck, C. Rauschenberg, and P. A. Matrai, 2012: On the chemical dynamics of extracellular polysaccharides in the high Arctic surface microlayer. Ocean Science, 8, 401418, doi: 10.5194/os-8-401-2012.

Goericke, R., and D. J. Repeta, 1992: The pigments of Prochlorococcus-marinus - the presence of divinyl chlorophyll-a and chlorophyll-b in a marine prokaryote. Limnology \& Oceanography, 37, 425-433.

Grossart, H. P., M. Simon, and B. E. Logan, 1997: Formation of macroscopic organic aggregates (lake snow) in a large lake: The significance of transparent exopolymer particles, phytoplankton, and zooplankton. Limnology \& Oceanography, 42, 1651-1659.

Hansell, D. A. and C. A. Carlson, 2001: Biogeochemistry of total organic carbon and nitrogen in the Sargasso Sea: control by convective overturn. Deep-Sea Research II 48, 1649-1667.

Harvey, G. W., 1966: Microlayer collection from the sea surface: a new method and initial results. Limnology \& Oceanography, 11, 608-613.

Harvey, G. W. and L. A. Burzell, 1972: Simple microlayer method for small samples. Limnology \& Oceanography, 17, 156-157.

Hawkins, L. N., and L. M. Russell, 2010: Polysaccharides, proteins, and phytoplankton fragments: Four chemically distinct types of marine primary organic aerosol classified by single particle spectromicroscopy. Advances in Meteorology, 2010, 612132, doi: $10.1155 / 2010 / 612132$

Hedges, J. I., B.A. Bergamaschi, and R. Benner, 1993: Comparative analyses of DOC and DON in natural waters. Marine Chemistry, 41,121-134.

Hobbie, J. E., R. J. Daley, and S. Jasper, 1977: Use of nuclepore filters for counting bacteria by fluorescence microscopy. Applied and Environmental Microbiology, 33, 1225-1228.

Hoffman, E. J., and R. A. Duce, 1974: Organic carbon content of marine aerosols collected on Bermuda. Journal of Geophysical Research, 79, 4474-4477.

Huffman, J. A., Treutlein, B., and U. Pöschl: 2010.Fluorescent biological aerosol particle concentrations and size distributions measured with an Ultraviolet Aerodynamic Particle Sizer (UVAPS) in Central Europe, Atmospheric Chemistry and Physics, 10, 3215-3233, doi:10.5194/acp-10-3215-2010.

Hultin, K. A. H., E. D. Nilsson, R. Krejci, E. M. Martensson, M. Ehn, A. Hagstrom, and G. de Leeuw, 2010: In situ laboratory sea spray production during the Marine Aerosol Production 2006 cruise on the northeastern Atlantic Ocean. Journal of Geophysical ResearchAtmospheres, 115. D06201, doi:10.1029/2009JD012522.

Ivosevic, M., R. A. Cairncross, and R. Knight, 2006: 3D predictions of thermally sprayed polymer splats: Modeling particle acceleration, heating and deformation on impact with a flat substrate. International Journal of Heat and Mass Transfer, 49, 3285-3297.

Jaenicke, R., 2005: Abundance of cellular material and proteins in the atmosphere, Science, 308, 73, doi:10.1126/science.1106335. 
Jeffrey, S. W., and S. W. Wright, 1997: Qualitative and quantitative HPLC analysis of SCOR reference algal cultures. In Phytoplankton Pigments in Oceanography: Guidelines to Modern Methods, ed S. WQ. Jeffrey, R.F.C. Mantoura, and S. W. Wright. Paris: UNESCO Publ.pp $343-360$.

Jeffrey SW, Wright SW, Zapata M (1999) Recent advances in HPLC pigment analysis of phytoplankton. Marine and Freshwater Research, 50, 879-896

Keene, W. C., Maring, H., Maben, J. R., Kieber, D. J., Pszenny, A. A. P., Dahl, E. E., Izaguirre, M. A., Davis, A. J., Long, M. S., Zhou, X. L., Sander, R. and L. Smoydzin, 2007: Chemical and physical characteristics of nascent aerosols produced by bursting bubbles at a model airsea interface. Journal of Geophysical Research-Atmospheres, 112, D21202, doi: 10.1029/2007JD008464.

Knopf, D. A., P. A. Alpert, B. Wang, and J. Y. Aller, 2011: Stimulation of ice nucleation by marine diatoms. Nature Geoscience, 4, 88-90.

Knopf, D. A., Alpert, P. A., Wang, B., O’Brien, R. E., Kelly, S. T., Laskin, A., Gilles, M. K., and R. C. Moffet, 2014: Micro-Spectroscopic Imaging and Characterization of Individually Identified Ice Nucleating Particles from a Case Field Study, Journal of Geophys.ical Research, 119, 17, 10,365-10,381, doi:10.1002/2014JD021866.

Knulst, J. C., D. Rosenberger, B. Thompson, and J. Paatero, 2003: Intensive sea surface microlayer investigations of open leads in the pack ice during Arctic Ocean 2001 Expedition. Langmuir, 19, 10194-10199.

Kuznetsova, M., and C. Lee, 2001: Enhanced extracellular enzymatic peptide hydrolysis in the sea-surface microlayer. Marine Chemistry, 73, 319-332.

Kuznetsova, M., C. Lee, and J. Aller, 2005: Characterization of the proteinaceous matter in marine aerosols. Marine Chemistry, 96, 359-377.

Kuznetsova, M., C. Lee, J. Aller, and N. Frew, 2004: Enrichment of amino acids in the sea surface microlayer at coastal and open ocean sites in the North Atlantic Ocean. Limnology \& Oceanography, 49, 1605-1619.

Ladino, L. A., Yakobi-Hancock, J. D., Kilthau, W. P., Mason, R. H., Si, M., Li, J., Miller, L. A., Schiller, C. L., Huffman, J. A., Aller, J. Y., Knopf, D. A., Bertram, A. K., and J. P. D. Abbatt, 2016: Addressing the ice nucleating abilities of marine aerosol: A combination of deposition mode laboratory and field measurements. Atmospheric Environment, 132, 1-10.

Laskin, A. Gilles, M. K., Knopf, D. A., Wang, B., and S. China, 2016: Progress in the Analysis of Complex Atmospheric Particles, Annual Reviews in Analytical Chemistry, 9, 117-143, doi: 10.1146/annurev-anchem-071015-041521

Leck, C., and E. K. Bigg, 1999: Aerosol production over remote marine areas - A new route. Geophysical Research Letters, 26, 3577-3580.

Leck, C., and E. K. Bigg, 2005: Source and evolution of the marine aerosol - A new perspective. Geophysical Research Letters, 32, L19803.

Leck, C., and E. K. Bigg, 2005: Biogenic particles in the surface microlayer and overlaying atmosphere in the central Arctic Ocean during summer. Tellus Series B-Chemical and Physical Meteorology, 57, 305-316.

Leck, C., K. Bigg, and M. Tjernström, 2005: Sources of biogenic aerosol particles over the central Arctic Ocean associated with the open lead surface microlayer. 38th Conference on Polar Meteorology and Oceanography, San Diego, Ca, 3.1.

Lewis, E. R., and S. E. Schwartz, 2004: Sea salt aerosol production: mechanisms, methods, measurements and models - a critical review. Geophysical Monograph, 152. 
Long, R. A., and F. Azam, 1996: Abundant protein-containing particles in the sea. Aquatic Microbial Ecology, 10, 213-221.

Long, M. S., W. C. Keene, D. J. Kieber, A. A. Frossard, L. M. Russell, J. R. Maben, J. D. Kinsey, P. K. Quinn, and T. S. Bates, 2014: Light-enhanced primary marine aerosol production from biologically productive seawater. Geophysical Research Letters, 41, 26612670, doi: 10.1002/2014GL059436.

Mackey, M.D., Mackey, D.J., Higgins, H.W. and Wright, S.W., 1996. CHEMTAX - A program for estimating class abundances from chemical markers: Application to HPLC measurements of phytoplankton. Marine Ecology Progress Series, 144(1-3): 265-283.

Marple, V. A., K. L. Rubow, and S. M. Behm, 1991: A Microorifice Uniform Deposit Impactor (MOUDI): Description, Calibration, and Use. Aerosol Science and Technology, 14, 434-446.

Mari, X. and A. Burd, 1998: Seasonal size spectra of transparent exopolymeric particles (TEP) in a coastal sea and comparison with those predicted using coagulation theory. Marine Ecology Progress Series, 163, 63-76.

Mason, R. H., Chou, C., McCluskey, C. S., Levin, E. J. T., Schiller, C. L., Hill, T. C. J., Huffman, J. A., DeMott, P. J., and A. K. Bertram, 2015: The micro-orifice uniform deposit impactor-droplet freezing technique (MOUDI-DFT) for measuring concentrations of ice nucleating particles as a function of size: improvements and initial validation. Atmospheric Measurement Techniques, 8, 2449-2462, doi: 10.5194/amt-8-2449-2015

Matrai, P. A., L. Tranvik, C. Leck, and J. C. Knulst, 2008: Are high Arctic surface microlayers a potential source of aerosol organic precursors? Marine Chemistry, 108, 109-122.

Middlebrook, A. M., D. M. Murphy, and D. S. Thomson, 1998: Observations of organic material in individual marine particles at Cape Grim during the First Aerosol Characterization Experiment (ACE 1). Journal of Geophysical Research-Atmospheres, 103, 16475-16483.

O'Dowd, C. D., Facchini, M. C., Cavalli, F., Ceburnis, D., Mircea, M., Decesari, S., Fuzzi, S., Yoon, Y. J., and J. P. Putaud, 2004: Biogenically driven organic contribution to marine aerosol. Nature, 431, 676-680.

O'Dowd, C. D., B. Langmann, S. Varghese, C. Scannell, D. Ceburnis, and M. C. Facchini, 2008: A combined organic-inorganic sea-spray source function. Geophysical Research Letters, 35, L01801, doi: 10.1029/2007GL030331.

Oppo, C., S. Bellandi, N. D. Innocenti, A. M. Stortini, G. Loglio, E. Schiavuta, and R. Cini, 1999: Surfactant components of marine organic matter as agents for biogeochemical fractionation and pollutant transport via marine aerosols. Marine Chemistry, 63, 235-253.

Orellana, M. V., P. A. Matrai, C. Leck, C. D. Rauschenberg, A. M. Lee, and E. Coz, 2011: Marine microgels as a source of cloud condensation nuclei in the high Arctic. Proceedings of the National Academy of Sciences of the United States of America, 108, 13,612-13,617, doi:10.1073/pnas.1102457108.

Ovadnevaite, J., C. O'Dowd, M. Dall'Osto, D. Ceburnis, D. R. Worsnop, and H. Berresheim, 2011: Detecting high contributions of primary organic matter to marine aerosol: A case study. Geophysical Research Letters, 38, L02807, doi: 10.1029/2010GL046083.

Ovadnevaite, J., Ceburnis, D.,Leinert, S., Dall'Osto, M., Canagaratna, M., O'Doherty, S., Berresheim, H., and C. O'Dowd, 2014: Submicron NE Atlantic marine aerosol chemical composition and abundance: Seasonal trends and air mass categorization. Journal of Geophysical Research-Atmospheres, 119, 11,850-11,863, 10.1002/2013JD021330.

Passow, U., 2000: Formation of transparent exopolymer particles, TEP, from dissolved precursor material. Marine Ecology Progress Series, 192, 1-11. 
Passow, U., 2002: Transparent exopolymer particles (TEP) in aquatic environments. Progress in Oceanography, 55, 287-333.

Passow, U., and A. L. Alldredge, 1995: A dye-binding assay for the spectrophotometric measurement of transparent exopolymer particles (TEP). Limnology \& Oceanography, 40, 1326-1335.

Pfeifer, S., Müller, T., K. Weinhold, N. Zikovam S. M.dos SantosA. Marinoni, O. F. Bischof, C. Kykal, L. Ries, F. Meinhardt, P. Aalto, N. Mihalopoulos, and A. Wiedensohler, 2016: Intercomparison of 15 aerodynamic particle size spectrometers (APS 3321): uncertainties in particle sizing and number size distribution. Atmospheric Measuremennt Technniques, 9, 1545-1551, doi: 10.5194/amt-9-1545-2016.

Pöhlker, C., Huffman, J. A., and U\&. Pöschl, 2012: Autofluorescence of atmospheric bioaerosols - fluorescent biomolecules and potential interferences, Atmospheric Measurement Techniques, 5, 37-71, doi: 10.5194/amt-5-37-2012.

Pöschl, U.: Atmospheric aerosols: Composition, transformation, climate and health effects, Angewandte Chemie International Edition., 44, 7520-7540, doi:10.1002/anie.200501122, 2005.

Prather, K. A., Bertram, Timothy H., Grassian, Vicki H., Deane, Grant B., Stokes, M. Dale, DeMott, Paul J., Aluwihare, Lihini I., Palenik, Brian P., and Coauthors, 2013: Bringing the ocean into the laboratory to probe the chemical complexity of sea spray aerosol.

Proceedings of the National Academy of Sciences of the United States of America, 110, 7550-7555, doi/10.1073/pnas.1300262110.

Putaud, J. P., Van Dingenen, R., Mangoni, M., Virkkula, A., Raes, F., Maring, H., Prospero, J. M., Swietlicki, E., Berg, O. H., Hillamo, R., and T. Makelã, 2000: Chemical mass closure and assessment of the origin of the submicron aerosol in the marine boundary layer and the free troposphere at Tenerife during ACE-2. Tellus Series B-Chemical and Physical Meteorology, 52, 141-168.

Quinn, P. K., and T. S. Bates, 2014: Ocean-Derived Aerosol and Its Climate Impacts. Treatise on Geochemistry (Second Edition), H. D. H. K. Turekian, Ed., Elsevier, 317-330.

Quinn, P. K., D. J. Coffman, V. N. Kapustin, T. S. Bates, and D. S. Covert, 1998: Aerosol optical properties in the marine boundary layer during the First Aerosol Characterization Experiment (ACE 1) and the underlying chemical and physical aerosol properties. Journal of Geophysical Research-Atmospheres, 103, 16547-16563.

Quinn, P. K., Bates, Timothy S., Schulz, Kristen S., Coffman, D. J., Frossard, A. A., Russell, L. M., Keene, W. C., and D. J. Kieber, 2014: Contribution of sea surface carbon pool to organic matter enrichment in sea spray aerosol. Nature Geoscience, 7, 228-232, doi: 101 038/NGE02092

Quinn, P. K., D. B. Collins, V. H. Grassian, K. A. Prather, and T. S. Bates, 2015: Chemistry and Related Properties of Freshly Emitted Sea Spray Aerosol. Chemical Reviews, 115 (10), 4383-4399, doi: 10.1021/cr500713g

Quinn, P. K., Bates, T. S., Coffman, D. J., Miller, T. L., Johnson, J. E., Covert, D. S., Putaud, J. P., Neususs, C., and T. Novakov, 2000: A comparison of aerosol chemical and optical properties from the 1st and 2nd Aerosol Characterization Experiments. Tellus Series BChemical and Physical Meteorology, 52, 239-257.

Rederstorff, E., Fatima, A. Ratiskol, J., Merceron, C., Vinatier, C., Weiss, P., and S. ColliecJouault, 2011: Sterilization of Exopolysaccharides Produced by Deep-Sea Bacteria: Impact on Their Stability and Degradation. Marine Drugs, 9, 224-241. 
Rinaldi, M., Fuzzi, S., Decesari, S., Marullo, S., Santoleri, R., Provenzale, A., von Hardenberg, J., Ceburnis, D., Vaishya, A., O'Dowd, C. D., and M.C. Facchini, 2013: Is chlorophyll-a the best surrogate for organic matter enrichment in submicron primary marine aerosol? Journal of Geophysical Research-Atmospheres, 118, 4964-4973. doi:10.1002/jgrd.50417.

Rolph, G. D.: Real-time Environmental Applications and Display sYstem (READY) Website. [Available online at http://ready.arl.noaa.gov.]

Russell, L. M., L. N. Hawkins, A. A. Frossard, P. K. Quinn, and T. S. Bates, 2010: Carbohydrate-like composition of submicron atmospheric particles and their production from ocean bubble bursting. Proceedings of the National Academy of Sciences of the United States of America, 107, 6652-6657, doi:10.1073/pnas.0908905107.

Schill, S. R., and Coauthors, 2015: The Impact of Aerosol Particle Mixing State on the Hygroscopicity of Sea Spray Aerosol. ACS Central Science, 1, 132-141.and Coauthors, 2012: Dissolved organic matter in sea spray: a transfer study from marine surface water to aerosols. Biogeosciences, 9, 1571-1582, doi: 10.5194/bg-9-1571-2012.

Sellegri, K., C. D. O'Dowd, Y. J. Yoon, S. G. Jennings, and G. de Leeuw, 2006: Surfactants and submicron sea spray generation. Journal of Geophysical Research-Atmospheres, 111, D22215, doi: 10.1029/2005JD006658.

Sieburth, J. M., 1983: Microbiological and organic-chemical processes in the surface and mixed layers. . Air-Sea Exchange of Gases and Particles P. S. Liss, and W. G. N. Slinn, Eds., Reidel Publishers Co, 121-172.

Stevenson, R. E., and A. Collier, 1962: Preliminary observations on occurrence of air-borne marine phytoplankton. Lloydia, 25, 89-\&.

Throndsen, J., 1978: Productivity and abundance of ultra-plankton and nanoplankton in Oslofjorden. Sarsia, 63, 273-284.

Van Heukelem, L., and C. S. Thomas, 2001: Computer-assisted high-performance liquid chromatography method development with applications to the isolation and analysis of phytoplankton pigments. Journal of Chromatography A, 910, 31-49.

Verdugo, P., 2012: Marine Microgels. Annual Review of Marine Science, Vol 4, C. A. Carlson, and S. J. Giovannoni, Eds., 375-400.

Verdugo, P., and P. H. Santschi, 2010: Polymer dynamics of DOC networks and gel formation in seawater. Deep-Sea Research Part I-Topical Studies in Oceanography, 57, 1486-1493.

Verdugo, P., A. L. Alldredge, F. Azam, D. L. Kirchman, U. Passow, and P. H. Santschi, 2004: The oceanic gel phase: a bridge in the DOM-POM continuum. Marine Chemistry, 92, 67-85.

Verdugo, P., M. V. Orellana, W.-C. Chin, T. W. Petersen, G. van den Eng, R. Benner, and J. I. Hedges, 2008: Marine biopolymer self-assembly: implications for carbon cycling in the ocean. Faraday Discussions, 139, 393-398.

Vignati, E., Facchini, M. C., Rinaldi, M., Scannell, C., Ceburnis, D., Sciare, J., Kanakidou, M., Myriokefalitakis, S., Dentener, F., and C.D. O'Dowd, 2010: Global scale emission and distribution of sea-spray aerosol: Sea-salt and organic enrichment. Atmospheric Environment, 44, 670-677, doi:10.1016/j.atmosenv.2009.11.013.

Wallace, G. T., D. F. Wilson, and G. I. Loeb, 1972: Flotation of particulates in sea water by rising bubbles. Journal of Geophysical Research, 77, 5293-5301.

Watson, S. W., T. J. Novitsky, H. L. Quinby, and F. W. Valois, 1977: Determination of bacterial number and biomass in marine environment. Applied and Environmental Microbiology, 33, 940-946. 
Wells, M. L., and E. D. Goldberg, 1993: Colloid aggregation in seawater. Marine Chemistry, 41, 353-358.

White R. H.1984: Hydrolytic stability of biomolecules at high temperatures and its implication for life at 250 degrees C. Nature, 310 (5976), 430-2, doi: 10.1038/310430a0.

Wilson, T. W., Ladino, L. A., Alpert, P. A., Breckels, M. N., Brooks, I. M., Browse, Jo., Burrows, S. M., Carslaw, K. S., Huffman, J. A., Judd, C., Kilthau, W. P., Mason, R. H., and Coauthors, 2015: A marine biogenic source of atmospheric ice-nucleating particles. Nature, 525, 234-238, doi: 10.1038/nature14986

Wurl, O., and M. Holmes, 2008: The gelatinous nature of the sea-surface microlayer. Marine Chemistry, 110, 89-97.

Yoon, Y. J., Ceburnis, D., Cavalli, F., Jourdan, O., Putaud, J. P., Facchini, M. C. Decesari, S., Fuzzi, S., Sellegri, K., Jennings, S. G. and C. D. O'Dowd, 2007: Seasonal characteristics of the physicochemical properties of North Atlantic marine atmospheric aerosols. Journal of Geophysical Research-Atmospheres, 112, D04206, doi: 10.1029/2005JD007044

Yun, U. J. and H. D. Park, 2003: Physical properties of an extracellular polysaccharide produced by Bacillus sp CP912. Letters in Applied Microbiology, 36(5), 282-287.

Zapata, M., S. W. Jeffrey, S. W. Wright, F. Rodriguez, J. L. Garrido, and L. Clementson, 2004: Photosynthetic pigments in 37 species (65 strains) of Haptophyta: implications for oceanography and chemotaxonomy. Marine Ecology Progress Series, 270, 83-102.

ZoBell, C. E., and H. M. Mathews, 1936: A qualitative study of the bacterial flora of sea and land breezes. Proceedings of the National Academy of Sciences of the United States of America, 22, 567-572. 